\title{
Pulling the Brakes on Fast and Furious Multiple Drug-Resistant (MDR) Bacteria
}

\author{
Abid Ali Khan ${ }^{1,2, *,+} \ddagger$, Khanzadi Nazneen Manzoor ${ }^{2,+}$, Aamir Sultan ${ }^{2}$, Maria Saeed ${ }^{2} \mathbb{D}$, Mahrukh Rafique $^{2}$, \\ Sameen Noushad ${ }^{2}$, Ayesha Talib ${ }^{3}$, Simone Rentschler ${ }^{1}$ and Hans-Peter Deigner $1,4,5, *, \ddagger$ (D)
}

Citation: Khan, A.A.; Manzoor, K.N.; Sultan, A.; Saeed, M.; Rafique, M.; Noushad, S.; Talib, A.; Rentschler, S.; Deigner, H.-P. Pulling the Brakes on Fast and Furious Multiple Drug-Resistant (MDR) Bacteria. Int. J. Mol. Sci. 2021, 22, 859. https:// doi.org/10.3390/ijms22020859

Received: 22 December 2020

Accepted: 13 January 2021

Published: 16 January 2021

Publisher's Note: MDPI stays neutral with regard to jurisdictional claims in published maps and institutional affiliations.

Copyright: (c) 2021 by the authors. Licensee MDPI, Basel, Switzerland. This article is an open access article distributed under the terms and conditions of the Creative Commons Attribution (CC BY) license (https:// creativecommons.org/licenses/by/ $4.0 /)$.
1 Center for Precision Medicine, Hochschule Furtwangen University, Jakob-Kienzle-Str. 17, 78054 Villingen-Schwenningen, Germany; s.rentschler@hs-furtwangen.de

2 Department of Biosciences, COMSATS University Islamabad, Park Road, Tarlai Kalan, Islamabad 45550, Pakistan; knazneen02@gmail.com (K.N.M.); rana.amir053@gmail.com (A.S.); maria.saeed93@yahoo.com (M.S.); mahrukhrafique93@gmail.com (M.R.); sameennoushad440@hotmail.com (S.N.)

3 Mechano(bio)chemistry, Max Planck Institute for Colloids and Interfaces, Am Mühlenberg 1, Golm, 14476 Potsdam, Germany; Ayesha.Talib@mpikg.mpg.de

4 EXIM Department, Fraunhofer Institute IZI, Leipzig, Schillingallee 68, 18057 Rostock, Germany

5 Faculty of Science, University of Tuebingen, Auf der Morgenstelle 8, 72076 Tuebingen, Germany

* Correspondence: abid.ali.khan@hs-furtwangen.de (A.A.K.); hans-peter.deigner@hs-furtwangen.de (H.-P.D.)

+ These authors contributed equally to this work.

$\ddagger \quad$ These authors contributed equally to this work.

\begin{abstract}
Life-threatening bacterial infections have been managed by antibiotics for years and have significantly improved the wellbeing and lifetime of humans. However, bacteria have always been one step ahead by inactivating the antimicrobial agent chemically or by producing certain enzymes. The alarming universal occurrence of multidrug-resistant (MDR) bacteria has compelled researchers to find alternative treatments for MDR infections. This is a menace where conventional chemotherapies are no longer promising, but several novel approaches could help. Our current review article discusses the novel approaches that can combat MDR bacteria: starting off with potential nanoparticles (NPs) that efficiently interact with microorganisms causing fatal changes in the morphology and structure of these cells; nanophotothermal therapy using inorganic NPs like AuNPs to destroy pathogenic bacterial cells; bacteriophage therapy against which bacteria develop less resistance; combination drugs that act on dissimilar targets in distinctive pathways; probiotics therapy by the secretion of antibacterial chemicals; blockage of quorum sensing signals stopping bacterial colonization, and vaccination against resistant bacterial strains along with virulence factors. All these techniques show us a promising future in the fight against MDR bacteria, which remains the greatest challenge in public health care.
\end{abstract}

Keywords: multidrug resistance; nanoantibiotics; nanoparticles; combination therapy; bacteriophages

\section{Introduction}

Infectious diseases around the globe, once cured with the help of the magical drugs "antibiotics", are now becoming a menace due to ever-increasing microbial antibiotic resistance. This emerging resistance is due to the irrational use of antibiotics in humans, veterinary, and agriculture because of their easy and unregulated access, especially in developing countries. This antibiotic resistance is either acquired naturally or artificially (by transfer of resistance genes) [1-3]. The occurrence of antibiotic resistance first became evident when Staphylococci encountered the first commercially produced antibiotic, penicillin, which produced an enzyme (penicillinase) to degrade it. The continuous use of diverse drugs has imposed a selective pressure on bacteria, transforming them into "superbugs", also known as multiple drug resistant (MDR) microorganisms [3]. MDR bacteria that are very difficult to treat include Pseudomonas aeruginosa, Acinetobacter baumannii, 
Escherichia coli, Klebsiella pneumoniae, vancomycin-resistant Enterococci (VRE), methicillinresistant Staphylococcus aureus (MRSA), vancomycin-resistant S. aureus (VRSA), and extensively drug-resistant (XDR) Mycobacterium tuberculosis [4]. Bacteria can exhibit resistance either naturally, i.e., entirely lacking the target or having low-affinity targets; by having the potential to inactivate the antibiotics; low cell permeability and the presence of efficient efflux pumps, by the transfer of resistant genes found on plasmids, transposons, and bacteriophages [1,2]. Different sophisticated mechanisms have been evolved by bacteria for resistance to antibiotics and to protect themselves from being killed by these antimicrobial agents [5]. Among these different mechanisms, one of the most successful processes is to inactivate the antimicrobial agent by chemically altering or destroying it. It is accomplished by producing certain enzymes, e.g., aminoglycoside modifying enzymes that modify the amino groups of aminoglycoside molecules, $\beta$-lactamases that destroy the amide bond of the $\beta$-lactam ring of $\beta$-lactam antibiotics [6]. Another mechanism of resistance is by decreasing the influx of antimicrobial agents in Gram-negative bacteria due to the presence of outer membrane, i.e., vancomycin resistance [7-9]. Efflux pumps present in bacteria are capable of secreting the antibiotic out of the cell are also one of the reasons for resistance to antimicrobial agents [10]. Another common strategy of resistance is to prevent antibiotic action by interfering with the target site in several ways like protecting (tetracycline and fluoroquinolones resistance) or modifying the target site (rifamycin resistance). Much astonishing diversity is present within these categories of mechanisms, and several types of resistance may be possessed by a single strain [5,11]. The general modes of resistance in bacteria are diagrammatically shown in Figure 1 . There are several mechanisms to prevent and combat these MDR bacteria. One of these includes nanoparticles (NPs) acting as a weapon against emerging antibiotic resistance. NPs (and nanoencapsulation platforms), due to their high surface area to volume ratio and functionalizable structural surface(s), can effectively interact with microorganisms causing fatal changes in the morphology and structure of these cells [12-14]. Nanophotothermal therapy is an approach in which inorganic NPs such as AuNPs can absorb magnetic radiation and convert it into heat, which can destroy pathogenic bacterial cells in the close locality. MDR bacteria are effectively killed by this technique [1,15-18]. Bacteriophage therapy is another mechanism to prevent the appearance of these lethal microorganisms. It is no less than a magical cure for many antimicrobial-resistant infections [3]. Bacteriophages are self-replicative, and bacteria develop less resistance against them when compared with the usage of antibiotics. To treat MDR bacteria, a suitable cocktail of phages is required [19].

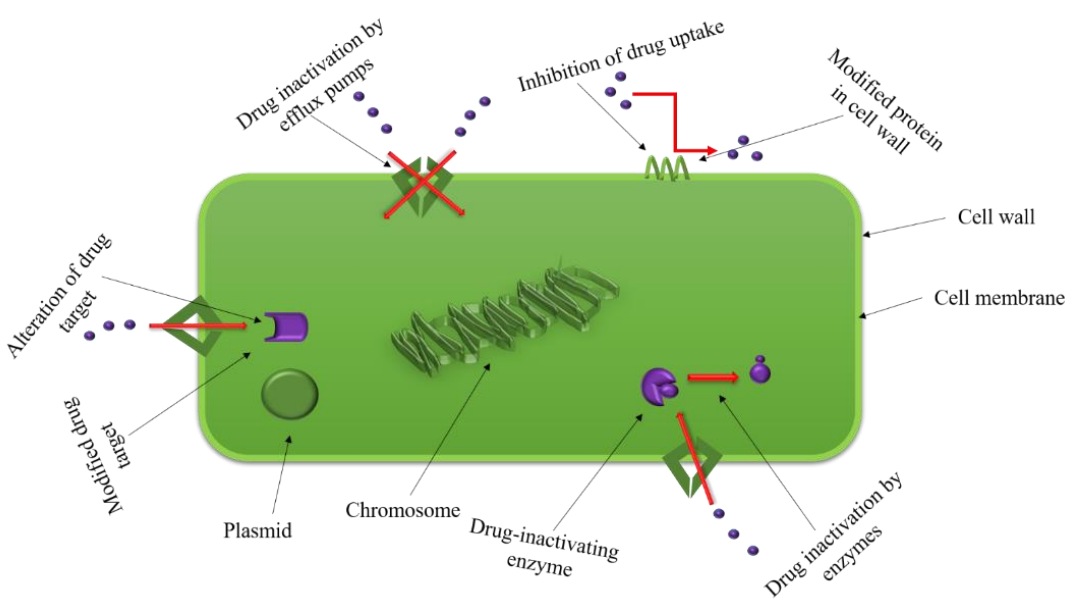

Figure 1. The possible ways a bacterium resists the action of an antibiotic drug.

Combination drugs that act on different targets in different pathways can be used in such a way that even if a bacterium is resistant to one of the drugs, the other drugs targeting different components of bacteria will disrupt them, thus minimizing their propagation [3]. Probiotics can also prevent antibiotic resistance by the secretion of antibacterial 
chemicals, diminishing the ability of bacteria to colonize the body, thereby reducing the use of antibiotics and hence the emergence of MDR [20,21]. Bacteria communicate with each other through quorum sensing; blockage of these signals would prevent bacterial colonization and therefore considerably reduce the need for antibiotics [22]. Vaccines lower the disease incidence and, concurrently, the need to use antimicrobial drugs. There is a potential prospect to develop vaccines against resistant bacterial strains as well as against virulence factors to step up the game against MDR bacteria [23]. Vaccines may be regarded as being superior to drugs due to being prophylactic and expressing multiple epitopes [24]. Figure 2 represents the different strategies and targets we can employ to fight multidrug resistance in bacteria.

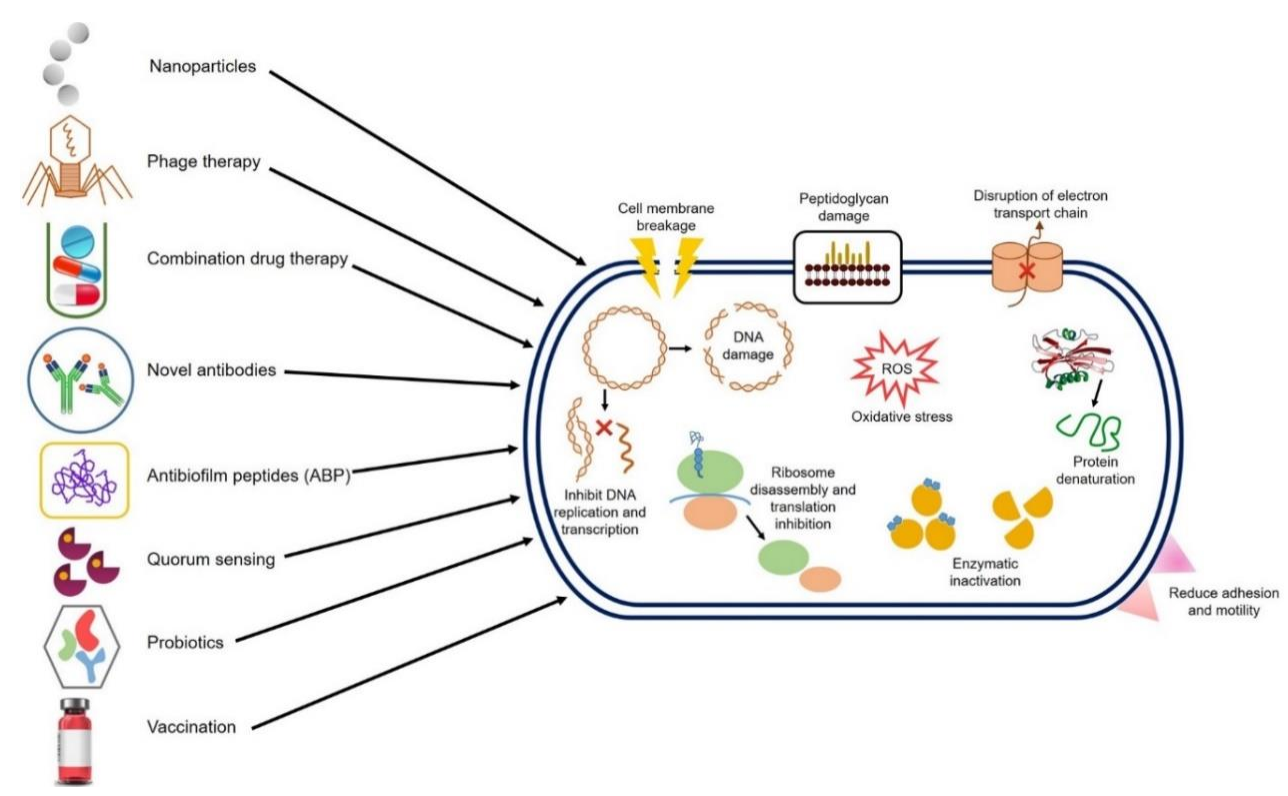

Figure 2. A pictorial presentation of various strategies, targets and effector molecules that can be used to curb the multiple drug resistance in bacterial pathogens.

2. Nanoparticles as a Weapon against Antibiotically Resistant Bacteria Extracorporally

Bacteria are responsible for causing a great variety of ailments each year around the globe, and the rapidly growing antibiotic resistance has caused an alarming situation in the field of medical microbiology. Infections due to MDR bacteria pose a great threat because they cause chronic disease states resulting in high rates of mortality, morbidity, and prolonged treatment costs [25]. MDR bacteria that are most problematic to deal with are XDR M. tuberculosis, A. baumannii, P. aeruginosa, MRSA, E. coli, and K. pneumoniae bearing NDM-1 (New Delhi metallo beta-lactamase-1), VRE, and VRSA [1,26,27]. NPs may serve as an imperative tool for fighting antibiotic resistance [28]. The general mode of antimicrobial action of different NPs is shown below, which is based on their exceptionally large surface area and functionalizable structure that enables them to effectively interact with microorganisms causing changes in the morphology and structure of bacterial cells (Figure 2) [1]. The basic mechanism includes anchoring the cell wall of a bacterium and penetrating it, altering the cell membrane permeability, or making it porous by the production of free radicals, ultimately causing cell death $[1,16,27,29]$.

Metallic NPs cause bacterial cell death by interacting with the sulfur and phosphorus in the bacterial DNA bases, thereby destroying the DNA. NPs can also inhibit signal transduction and, consequently, bacterial growth by the dephosphorylation of peptide substrates on tyrosine residues $[1,30,31]$. Certain NPs can destroy the membrane potential and suppressing the ATPase activities to reduce the levels of ATP in the cell, while others by inhibiting ribosomal subunit from binding the tRNA molecules $[1,32,33]$. Li et al. reported that $2 \mathrm{~nm}$ AuNPs with cationic surface chemistry could interact with the cell 
membrane of Gram-positive and Gram-negative bacteria resulting in the formation of distinct aggregation patterns and promote bacterial cell lysis $[34,35]$. Correspondingly, Jiang et al. also established that bacterial cell membrane could be damaged by cationic AuNPs induced protuberance $[35,36]$.

\subsection{Metal Oxide, Nitric Oxide, and Chitosan NPS}

Metal oxide NPs such as $\mathrm{TiO}_{2}, \mathrm{CuO}$, and $\mathrm{ZnO}$, by the production of reactive oxygen species (ROS), also act as antibacterial agents against MRSA and E. coli, but their efficiency is increased when they are coupled with AgNPs. They have photocatalytic activity due to a wide bandgap, which is attributed to the production of ROS [1,37,38]. CuONPs have shown to be effective against a variety of bacterial pathogens, including MRSA, E. coli, S. aureus, $P$. aeruginosa, $N$. meningitis, $B$. cereus, $S$. pyogenes, and A. baumannii $[1,26,39,40]$. The mode of action of AgNps is shown in Figure 3. When CuONPs are conjugated with AgNPs, their antibacterial activity is enhanced so that they can completely inhibit bacterial growth. $Z n O N P s$ have shown acute toxicity to antibiotic (methicillin)-resistant bacteria such as $S$. aureus and S. agalactiae. ZnONPs are internalized into the cells where they disorganize and damage the cell, cell membrane and also increase the oxidative stress that damages bacterial proteins, lipids, and DNA [1,41,42]. However, at low concentration, ZnONPs show slight toxicity indicating that the level of toxicity caused by these NPs depends upon their concentration. The colloidal suspension of $\mathrm{ZnO}$ is found to inhibit $90 \%$ of MRSA, E. faecalis, a high biofilm-producing strain S. epidermidis, and the growth of several other clinically relevant pathogens. ZnONPs were also shown to inhibit bacterial growth of methicillin-sensitive Staphylococcus aureus (MSSA), MRSA, and methicillin-resistant Staphylococcus epidermidis (MRSE) strains. Moreover, these NPs were also found to be effective against extended-spectrum $\beta$-lactamases-producing E. coli and K. pneumoniae apart from other bacteria like Vibrio cholera and Campylobacter jejuni [1,43-46].

Nitric-oxide-releasing NPs (NONPs) also act as antimicrobial agents against many antibiotic-resistant and sensitive bacteria, i.e., K. pneumoniae, E. faecalis, S. pyogenes, E. coli, and $P$. aeruginosa. NO is unstable in the presence of oxygen and reacts with oxygen or superoxide spontaneously to produce reactive nitrogen and oxygen intermediates that are toxic against cells and act as antimicrobial species. When the concentration of $\mathrm{NO}$ is greater than $1 \mu \mathrm{M}$, these intermediate species become significantly important because, at these concentrations, reactive nitrogen species (RNOS) like S-nitrosothiols (RSNO), peroxynitrite $(\mathrm{OONO}-)$, nitrogen dioxide $\left(\mathrm{NO}_{2}\right)$ are produced $[1,47,48]$. Peroxynitrite and nitrogen dioxide have demonstrated NO-associated lipid damage, which shows the antimicrobial activities associated with $\mathrm{NO}[1,49,50]$.

NO interactions with proteins involve reactive thiols, heme groups, iron-sulfur clusters, phenolic or aromatic amino acid residues, tyrosyl radicals, or amines. Peroxynitrite and $\mathrm{NO}_{2}$ also nonspecifically oxidize proteins at many sites. $\mathrm{NO}$ can also inactivate the enzymes containing Fe-S clusters (e.g., aconitase, NADH dehydrogenase, succinate dehydrogenase), thereby suggesting that $\mathrm{NO} \bullet$ (NO radicals) may cause the release of iron from metalloenzymes and result in iron depletion $[1,51,52]$. The enzymes DNA alkyl transferases have cysteine residues where the $-\mathrm{SH}$ group of cysteine residues reacts with $\mathrm{NO}$, resulting in the formation of S-NO adducts. These adducts, in turn, inhibit the transfer of the alkyl group from guanine to the protein. Thus, NO inhibits DNA repair enzymes, which are particularly concerned with the repair of alkylation to DNA [53,54]. The sensitivity of prokaryotes to NPs treatment is higher because bacteria depend a great deal on iron-sulfur clusters as compared to mammalian cells. Consequently, it seems reasonable that efficient NO-releasing NPs have the potential to be effective against MDR bacteria [1,55]. The in vitro efficacy of NONPs has been assessed against several clinically significant Grampositive (E. faecalis and S. pyogenes) and negative (E. coli, K. pneumoniae, and P. aeruginosa) isolates. It was found that the reduction in bacterial growth was NONPs dose-dependent for both Gram-negative as well as Gram-positive bacteria. The growth of Gram-negative 
bacterial isolates was inhibited within $24 \mathrm{~h}$ by NONPs; however, Gram-positive bacterial growth was inhibited within $8-16 \mathrm{~h}$ with lower NONPs concentrations [1,56,57].

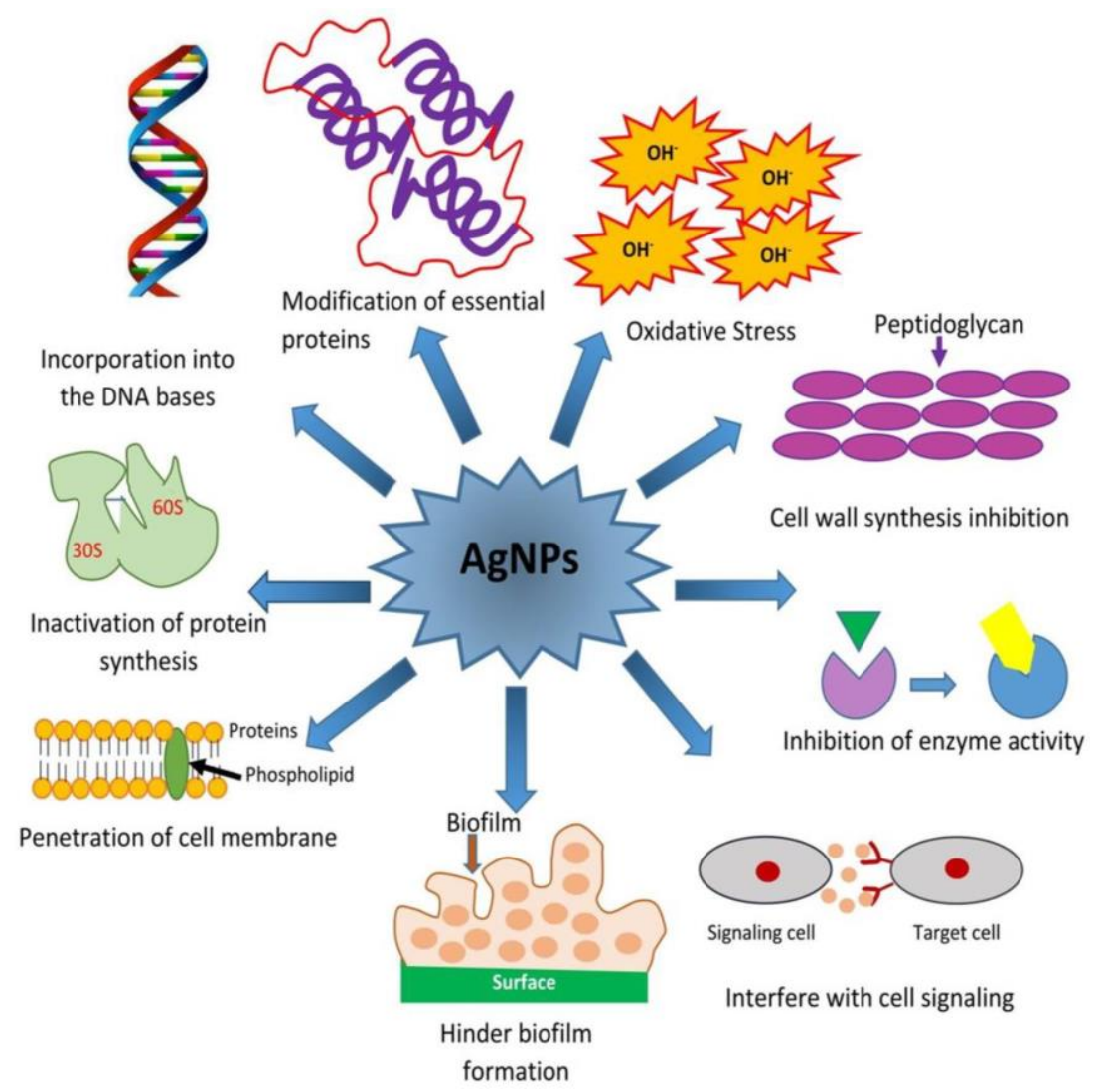

Figure 3. Different modes of action possible for the eradication (killing) of bacterial cells through silver (Ag) nanoparticles [1].

Chitosan NPs are known to be suitable for non-invasive routes of drug administration (nasal, oral, ocular, and pulmonary routes) as they deliver the drug with reduced toxicity, increase the blood half-life of drugs as well as the efficiency of intravenous injections $[58,59]$. Biofilms produced by P. aeruginosa are one of the main challenges while treating (the skin) infections. In one study, gold nanorods (AuNR) were decorated with 1,2-Distearoyl-snglycero-3-phosphorylethanolamine(DSPE) phospholipids and exploited to destroy biofilms produced by $P$. aeruginosa In vitro. Roughly a $\sim 6 \log$ cycle reduction of the bacterial count was observed by applying DSPE-AuNR against P. aeruginosa, proving the fact that goldbased nanosystem is one of the effective alternatives to antibiotics for the eradication of biofilms [60]. In another report, the effect of hyperthermia of gold nanorods (GNR) against S. aureus and Propionibacterium acnes, the causative agents of acne vulgaris, were evaluated. Local heat was generated when functionalized GNR was excited by a laser beam. It resulted in a $\geq 99.99 \%$ reduction of viable bacterial count [61].

\subsection{Nano-Photothermal Therapy of MDR Bacteria}

Another technique employed for destroying biological cells is Photothermal therapy with NPs. In this technique, the electromagnetic radiation absorbed by the NPs is converted into heat, which is then transferred via thermal conduction to the bacteria or cells in close proximities $[1,18,62]$. AuNPs have been extensively studied for photothermal therapy of cancer [1,63-65]. It has been shown that pathogenic bacteria can also be selectively killed by using functionalized AuNPs. AuNPs, when conjugated with vancomycin, acquire a polygonal shape, due to which these NPs have the potential of absorbing near-infrared (NIR) light. Amoxicillin coated Au-NPs have increased in vivo stability $[1,66,67]$. NPs conjugated with vancomycin can effectively kill bacterial cells under illumination (>99\%). 
It has been established that pathogenic E. coli can be photothermally lysed using Au nanorods $[1,29,68]$, and $P$. aeruginosa can also be effectively killed by the same metallic nanorods conjugated with primary antibodies [1,69].

The bacterial cell viability also reduces significantly when a nanorod attaches to the surface of the bacterial cells and is exposed to near-infrared radiation. In addition, the MDR bacteria are photothermally destroyed by multifunctional popcorn-shaped magnetic iron core-shell gold nanoparticles. Results had shown that when MDR Salmonella DT104 bacterial cells were treated with M3038 antibody-conjugated hybrid platforms, they attached to bacterial cells, and localized heating at $670 \mathrm{~nm}$ light irradiation caused irreparable cellular damage and killed the bacteria within $10 \mathrm{~min}$ of exposure [70]. MRSA and E. coli had been reported to show a significant decrease in viable counts when exposed to $660 \mathrm{~nm}$ for 5 minutes, along with polysiloxane polymers containing embedded methylene blue and AuNPs $[1,71,72]$.

\subsection{Silver NPs Bactericidal Effect against Multidrug-Resistant Bacteria}

Historically silver has been used for its antiseptic and bactericidal activity in dental alloys and open wounds as well as in Ayurveda and homeopathy. Gram-positive bacteria possess a thick peptidoglycan layer $(30 \mathrm{~nm})$ in comparison to Gram-negative bacteria $(2-3 \mathrm{~nm})$, and silver NPs are thought to anchor the cell wall leading to structural changes in the cell membrane, thus increasing the cell permeability. Therefore, uncontrolled transport through the cell membrane results in bacterial cell death [34]. In addition, AgNPs produce free radicals for membrane damage and may affect the proton motive force inhibiting the oxidative phosphorylation [55]. AgNPs can release $\mathrm{Ag}^{+}$ions, which can disrupt cellular functions by interacting with thiol groups of many enzymes rendering them inactive $[1,73,74]$. Panacek et al. established that the colloidal AgNPs have substantial bactericidal activity against MRSA, Gram-positive and Gram-negative bacteria [55]. Ayala-Nunez et al. observed that the mode of action of AgNPs (100 nm size) is dosedependent against MRSA and non-MRSA as their growth was inhibited at concentrations over $1.35 \mathrm{mg} / \mathrm{mL}$ when the inoculum was $10^{5}$-CFU / mL [55,75]. Nanda and Saravanan reported the antimicrobial activity of AgNPs synthesized by aqueous $\mathrm{Ag}^{+}$reduction with S. aureus against MRSA, MRSE, S. pyogenes, Salmonella typhi, and K. Pneumoniae and reported that AgNPs were most effective against MRSA followed by MRSE and S. pyogenes, but only moderate activity was observed against $S$. typhi and K. pneumoniae $[55,76]$. Humberto et al. found that AgNPs of concentration 30 to $100 \mathrm{mmol} / \mathrm{L}$ is effective against the erythromycin-resistant $S$. pyogenes, ampicillin-resistant E. coli, MDR P. aeruginosa, and drugsusceptible strains including Streptococcus spp., E. coli, and P. aeruginosa [55,77]. Pal et al. found that triangular AgNPs are more active than spherical NPs, which are again more active than rod-shaped NPs against $E$. coli. Morones et al. studied the effect of different concentrations of AgNPs (1-100 nm size) on E. coli and concluded that concentration over $75 \mu \mathrm{g} / \mathrm{mL}$ was sufficient for a significant decline in the bacterial progression. Shrivastava et al. found that the mode of action of AgNPs is dose-dependent and is more evidence against Gram-negative bacteria as compared to Gram-positive bacteria [55]. Recently, our group reported that AgNPs synthesized through green routes can check many susceptible and MDR bacteria very effectively [26]. The bactericidal effect of AgNPs against MDR bacteria is illustrated in Figure 4. 


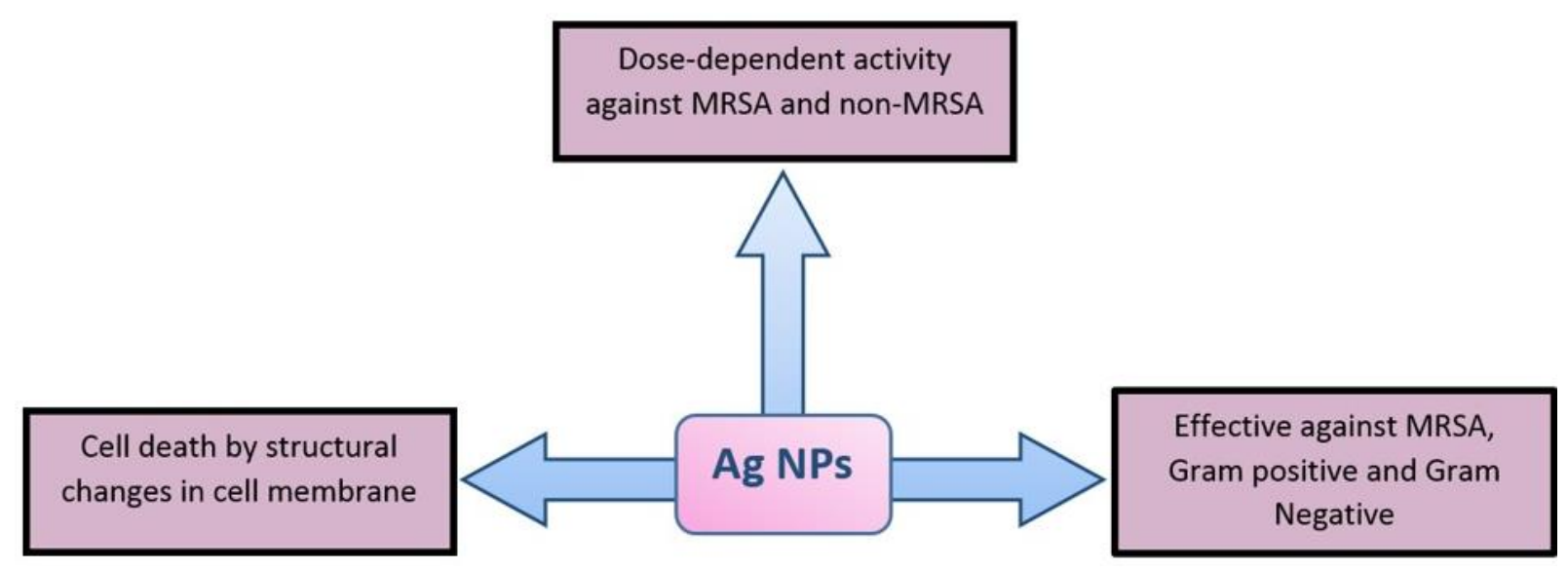

Figure 4. Mode of action (bactericidal effects) of AgNPs against bacteria against MRSA.

The antibacterial activity of NPs is directed by their physicochemical properties, which in turn depend upon the route(s) of synthesis [1,78]. It has been reported that NPs could be synthesized by Fungi like Fusarium oxysporum and Phanerochaete chrysosporium. Magnetotactic bacteria are also well known to biosynthesize magnetic iron oxide nanoparticles $[79,80]$. Biosynthetically produced AgNPs using fungus, yeast, bacteria, and plant extracts were found to have strong antibacterial efficacy against various MDR pathogens such as M. tuberculosis, P. aeruginosa, S. pneumoniae, MRSA, K. pneumoniae, MRSE, S. pyogenes, Bacillus spp., E. coli and S. typhi $[1,77,81,82]$. Green NPs have improved antibacterial activity because of their high surface area to volume ratio and surface reactivity as compared to the chemical NPs. In addition, the coating of biosynthetically produced NPs by phytochemicals increased their ability to inhibit bacterial growth in comparison to chemical NPs $[1,83,84]$.

\subsection{Aluminum Oxide Nanoparticles}

The antimicrobial effects of metallic NPs, particularly AgNPs, have been extensively reviewed, but there is not enough substantial literature regarding the antimicrobial activities of Aluminum oxide NPs. Aluminum oxide NPs, also called alumina, are normally known as corundum, which is the crystalline form of alumina $\left(\mathrm{Al}_{2} \mathrm{O}_{3}\right)$ [33]. They adopt a corundum-like structure as oxygen forms a hexagonal packing, and $\mathrm{Al}^{+3}$ fills two-third of the lattice in the octahedral sites [85]. Alumina NPs possess a positive charge on their surface at almost neutral $\mathrm{pH}$ and are thermodynamically stable over a wide range of temperatures. They can disrupt the bacterial cell wall by producing ROS resulting in bacterial cell death [86]. Among the various diverse procedures for the synthesis of Alumina NPs, for instance, hydrothermal processing, sol-gel pyrolysis, sputtering; the laser ablation method is widely used as it is a quick and high-purity process [87]. Aluminum NPs have been documented to have a wide range of antimicrobial activities. Their growth-inhibitory effects on E. coli have been reported at 10-1000 $\mu \mathrm{g} / \mathrm{mL}$ [88]. Balasubramanyam et al. have reported high sensitivity of Alumina against $P$. fluorescence as compared to the bulk materials [89]. In one study, aluminum oxide NPs were proven to be a good antibacterial agent against Gram-positive as well as Gram-negative bacteria. These NPs were synthesized by using aluminum sulfate and $\mathrm{NaOH}$ as precursors by the co-precipitation method. Their activity was analyzed against Gram-positive (S. aureus and Streptococcus mutans) and Gram-negative (E. coli and Proteus vulgaris) bacteria [90].

An oxide layer is produced over alumina nanoparticles, which then protects these from oxidation. These particles are affected by different $\mathrm{pH}$ concentrations, which lead to their different toxicity levels; for example, at neutral $\mathrm{pH}$, these NPs have a positive surface charge due to which they would have an affinity towards the negatively charged surface of $E$. coli cells, thereby resulting in adhesion of alumina NPs over the bacterial surface. Moreover, these NPs also can serve as radical scavengers and cause distortion in bacterial cells [91]. 


\subsection{Silicon NPS}

Silicon dioxide $\left(\mathrm{SiO}_{2}\right)$ is one of the important industrial additives with several applications. It is commonly used as a semiconductor in electronics when in the crystallized form [92]. The conversion to metal oxide increases the surface area, thereby providing better performance in applications. Jiang et al. have shown the binding of $\mathrm{SiO}_{2} \mathrm{NPs}$ to the bacterial cell walls as well as their higher toxicity as compared to their bulkier counterparts [93]. As limited data are available regarding the antibacterial activity of $\mathrm{SiO}_{2} \mathrm{NPs}$, more research is needed to be done to understand their clear role. For treating multidrugresistant $M$. tuberculosis, ethionamide (ETH) is one of the most important drugs used. In one study, it was reported that loading ETH into thermally carbonized-porous silicon (TCPSi) nanoparticles would result in enhancement of solubility and permeability of ETH at different $\mathrm{pH}$-values as well as increased its metabolization process. It was found that ETH-conjugated SiNPs tend to reduce the dosing frequency of ETH for the treatment of multidrug-resistant $M$. tuberculosis [94]. Moreover, it was demonstrated in a study that porous silicon nanoparticles have the potential to be used as a means of a prolonged drug delivery system [95].

\subsection{Gallium Nanoparticles (NPs)}

There is a growing problem of drug-resistant strains of $M$. tuberculosis, due to which there is an urgent need for new treatments and novel drugs. In one study, targeted drug delivery using gallium (III) nano-formulations were used against drug-resistant M. tuberculosis, which showed promising anti-tuberculous activity. They also promoted maturation of the phagosome, which in turn result in the increased macrophage-mediated killing of the organism.

M. tuberculosis requires iron for growth and replication, gallium encapsulated in nanoparticles interferes with the cellular iron acquisition and utilization, which in turn inhibit the growth of this bacteria human monocyte-derived macrophages (MDMs). Delivery of Ga in the form of nanoparticles to macrophages open new pathways for the development of new therapeutic anti-tuberculous drugs [96]. Similar to M. tuberculosis, iron and gallium encapsulated in nanoparticles can also be used against HIV. GaNPs are readily internalized by the MDMs, and then sustained drug release causes significant growth inhibition of both HIV and M. tuberculosis. Iron-mediated enzymatic reactions are interrupted by GaNPs, which leads to growth inhibition of HIV-M. tuberculosis coinfection in macrophages, and it also modulates the release of cytokines that may contribute to HIV-TB pathogenesis [97]. Table 1 summarizes different nanoparticles that can be exploited as a weapon against multidrug-resistant bacteria.

Table 1. Use of different nanoparticles as a weapon against drug-resistant bacteria.

\begin{tabular}{|c|c|c|c|c|}
\hline Agent & Target Bacteria/Diseases & $\begin{array}{c}\text { Mode of } \\
\text { Action/Description }\end{array}$ & $\begin{array}{c}\text { Notes (Advantages (a), } \\
\text { Limitations (1), Combination } \\
\text { Strategy (c)) }\end{array}$ & Ref. \\
\hline \multicolumn{5}{|c|}{ Nanoparticles } \\
\hline $\begin{array}{l}\text { AuNP with cationic } \\
\text { surface chemistry }\end{array}$ & $\begin{array}{l}\text { Gram-positive and } \\
\text { Gram-negative bacteria }\end{array}$ & $\begin{array}{l}\text { Interaction with cell } \\
\text { membrane } \rightarrow \text { formation of } \\
\text { aggregates } \rightarrow \text { bacterial cell } \\
\text { lysis; cause protuberance }\end{array}$ & $\begin{array}{l}\text { (a) Unique electronic, sensing, } \\
\text { optical, and biochemical } \\
\text { properties }\end{array}$ & {$[34-36,98]$} \\
\hline CuONP & $\begin{array}{c}\text { Variety pathogens, } \\
\text { including MRSA, E. coli, } S \text {. } \\
\text { aureus, P. aeruginosa, } N . \\
\text { meningitis, B. cereus, } S . \\
\text { pyogenes, A. baumannii }\end{array}$ & $\begin{array}{c}\text { ROS } \rightarrow \text { induce oxidative } \\
\text { stress }\end{array}$ & $\begin{array}{l}\text { (c) Antibacterial activity } \\
\text { enhanced by conjugation with } \\
\text { AgNPs (photocatalytic activity } \\
\text { attributed to the production of } \\
\text { ROS) }\end{array}$ & {$[1,38-40,99]$} \\
\hline
\end{tabular}


Table 1. Cont.

\begin{tabular}{|c|c|c|c|c|}
\hline Agent & Target Bacteria/Diseases & $\begin{array}{c}\text { Mode of } \\
\text { Action/Description }\end{array}$ & $\begin{array}{c}\text { Notes (Advantages (a), } \\
\text { Limitations (1), Combination } \\
\text { Strategy (c)) }\end{array}$ & Ref. \\
\hline $\begin{array}{l}\text { ZnONPs, colloidal } \\
\text { ZnO suspension }\end{array}$ & $\begin{array}{l}\text { MRSA, S. agalactiae, MRSE, } \\
\text { MSSA, ESBL-producing E. } \\
\text { coli and K. pneumoniae, } \\
\text { Vibrio cholera, Campylobacter } \\
\text { jejuni, E. faecalis, } S . \\
\text { epidermidis, and other } \\
\text { clinically relevant } \\
\text { pathogens }\end{array}$ & $\begin{array}{l}\text { Disorganization and } \\
\text { damage of cell, cell } \\
\text { membrane after } \\
\text { internalization; damage of } \\
\text { proteins, lipids, and DNA } \\
\text { via oxidative stress }\end{array}$ & $\begin{array}{l}\text { (l) Level of toxicity concentration } \\
\text { dependent } \\
\text { (c) Antibacterial activity } \\
\text { enhanced by conjugation with } \\
\text { AgNPs }\end{array}$ & {$[1,41-46]$} \\
\hline $\begin{array}{l}\text { Nitric-oxide- } \\
\text { releasing NPs } \\
\text { (NONPs) }\end{array}$ & $\begin{array}{l}\text { Antibiotic-resistant and } \\
\text { sensitive bacteria, i.e., } K \text {. } \\
\text { pneumoniae, E. faecalis, } S \text {. } \\
\text { pyogenes, E. coli, and } P \text {. } \\
\text { aeruginosa }\end{array}$ & $\begin{array}{c}\text { Formation of cell toxic } \\
\text { reactive nitrogen and } \\
\text { oxygen intermediates, } \\
\text { NO-associated lipid } \\
\text { damage, iron depletion, } \\
\text { inhibition of DNA repair } \\
\text { enzymes }\end{array}$ & $\begin{array}{l}\text { (a) NO is unstable so } \\
\text { spontaneously generate reactive } \\
\text { intermediates }\end{array}$ & {$[47-54]$} \\
\hline \multirow[t]{2}{*}{ Gold nanorods } & P. aeruginosa & $\begin{array}{l}\text { Conjugated with primary } \\
\text { antibodies }\end{array}$ & $\begin{array}{l}\text { (a) Eradicate biofilms } \\
\text { (c) 1,2-Distearoyl-sn-glycero-3- } \\
\text { phosphorylethanolamine } \\
\text { (DSPE) }\end{array}$ & {$[60,69]$} \\
\hline & $\begin{array}{c}\text { S. aureus and } \\
\text { Propionibacterium acnes }\end{array}$ & $\begin{array}{l}\text { Local hyperthermia by } \\
\text { laser beam excited } \\
\text { functionalized gold } \\
\text { nanorods }\end{array}$ & $\begin{array}{l}\text { (a) Enhanced reduction of viable } \\
\text { bacterial count }\end{array}$ & {$[61]$} \\
\hline $\begin{array}{l}\text { AgNPs, colloidal } \\
\text { AgNPs }\end{array}$ & $\begin{array}{c}\text { Gram-positive and } \\
\text { Gram-negative bacteria; } \\
\text { drug-susceptible strains } \\
\text { including Streptococcus } \\
\text { spp., E. coli, and } P . \\
\text { aeruginosa; } \\
\text { MRSA, MRSE, } \\
\text { (erythromycin-resistant) } S . \\
\text { pyogenes, } \\
\text { (ampicillin-resistant) E. coli, } \\
\text { MDR P. aeruginosa }\end{array}$ & $\begin{array}{l}\text { AgNPs anchor to cell wall } \\
\text { leading to increased cell } \\
\text { permeability by structural } \\
\text { changes } \rightarrow \text { uncontrolled } \\
\text { transport through cell } \\
\text { membrane; } \\
\text { Membrane damage caused } \\
\text { by AgNP produced free } \\
\text { radicals; } \\
\text { released Ag }{ }^{+} \text {ions } \\
\text { inactivate enzymes by } \\
\text { interacting with thiol } \\
\text { groups of enzymes }\end{array}$ & $\begin{array}{l}\text { (a) Bactericidal against } \\
\text { Gram-positive as well as } \\
\text { Gram-negative bacteria } \\
\text { (1) Dose-dependent }\end{array}$ & {$[55,74-76]$} \\
\hline $\begin{array}{l}\text { Biosynthetically } \\
\text { produces AgNPs } \\
\text { using fungus, yeast, } \\
\text { bacteria, and plant } \\
\text { extracts }\end{array}$ & $\begin{array}{c}\text { M. tuberculosis, } P \text {. } \\
\text { aeruginosa, S. pneumoniae, } \\
\text { MRSA, K. pneumoniae, } \\
\text { MRSE, S. pyogenes, Bacillus } \\
\text { spp., E. coli and S. typhi }\end{array}$ & $\begin{array}{l}\text { Inhibit cell wall synthesis, } \\
\text { protein synthesis, which is } \\
\text { mediated by the } 30 \mathrm{~s} \\
\text { ribosomal subunit, and } \\
\text { nucleic acid synthesis }\end{array}$ & $\begin{array}{l}\text { (a) Strong antibacterial efficacy } \\
\text { against various MDR pathogens }\end{array}$ & [81-83] \\
\hline $\begin{array}{l}\text { Aluminum oxide } \\
\text { NPs }\end{array}$ & $\begin{array}{c}\text { E. coli, Pseudomonas } \\
\text { fluorescence, Staphylococcus } \\
\text { aureus, Streptococcus mutans, } \\
\text { Proteus vulgaris) }\end{array}$ & $\begin{array}{l}\text { Disruption of bacterial cell } \\
\text { wall by producing ROS, } \\
\text { Serve as radical scavengers } \\
\text { leading to distortion in } \\
\text { bacterial cells }\end{array}$ & $\begin{array}{l}\text { (a) Thermodynamically stable } \\
\text { over a wide range of } \\
\text { temperatures }\end{array}$ & [88-90] \\
\hline
\end{tabular}


Table 1. Cont.

\begin{tabular}{|c|c|c|c|c|}
\hline Agent & Target Bacteria/Diseases & $\begin{array}{c}\text { Mode of } \\
\text { Action/Description }\end{array}$ & $\begin{array}{l}\text { Notes (Advantages (a), } \\
\text { Limitations (1), Combination } \\
\text { Strategy (c)) }\end{array}$ & Ref. \\
\hline $\begin{array}{l}\text { Ethionamide } \\
\text { (ETH)-conjugated } \\
\text { SiNPs } \\
\text { (silicon) }\end{array}$ & $\begin{array}{l}\text { Multidrug-resistant } M . \\
\text { tuberculosis }\end{array}$ & $\begin{array}{l}\text { Enhance solubility and } \\
\text { permeability of ETH at } \\
\text { different pH-values }\end{array}$ & $\begin{array}{c}\text { (a) Reduction of dosing } \\
\text { frequency of ETH for the } \\
\text { treatment of multidrug-resistant } \\
M \text {. tuberculosis } \\
\text { (c) thermally carbonized-porous } \\
\text { silicon (TCPSi) loaded with } \\
\text { ethionamide (ETH) }\end{array}$ & [94] \\
\hline $\begin{array}{c}\text { Gallium (III) } \\
\text { nano-formulations }\end{array}$ & $\begin{array}{l}\text { Drug-resistant } M \text {. } \\
\text { tuberculosis }\end{array}$ & $\begin{array}{c}\text { Targeted drug delivery, } \\
\text { Promotion of maturation of } \\
\text { phagosome } \rightarrow \text { increased } \\
\text { macrophage-mediated } \\
\text { killing, } \\
\text { Interruption of } \\
\text { iron-mediated enzymatic } \\
\text { reactions }\end{array}$ & $\begin{array}{c}\text { (a) Active against resistant } \\
\text { bacteria like M. tuberculosis, HIV }\end{array}$ & [96] \\
\hline \multicolumn{5}{|c|}{ Nano-photothermal therapy } \\
\hline AuNPs & $\begin{array}{l}\text { Gram-positive bacteria, } \\
\text { Gram-negative bacteria }\end{array}$ & $\begin{array}{l}\text { Electromagnetic radiation } \\
\text { absorbed by the NPs } \\
\text { converted into heat } \rightarrow \\
\text { transferred via thermal } \\
\text { conduction to bacteria in } \\
\text { close proximities }\end{array}$ & $\begin{array}{l}\text { (c) Conjugated with vancomycin } \\
\text { or amoxicillin }\end{array}$ & {$[62,63,67]$} \\
\hline Au nanorods & Pathogenic E. coli & $\begin{array}{l}\text { Generate heat that lyses } \\
\text { bacteria }\end{array}$ & $\begin{array}{c}\text { (c) Heat generated by using } \\
\text { continuous-wave laser } \\
\text { irradiation or near-infrared laser }\end{array}$ & [29] \\
\hline Au nanorods & P. aeruginosa & $\begin{array}{c}\text { Nanorod attach to the } \\
\text { bacterial cell surface allows } \\
\text { the cell to expose to } \\
\text { near-infrared radiation }\end{array}$ & $\begin{array}{l}\text { (c) Conjugated with primary } \\
\text { antibodies }\end{array}$ & {$[1,69]$} \\
\hline $\begin{array}{l}\text { Multifunctional } \\
\text { popcorn-shaped } \\
\text { magnetic iron } \\
\text { core-shell gold } \\
\text { nanoparticles }\end{array}$ & Salmonella DT104 & $\begin{array}{l}\text { Selective and irreparable } \\
\text { cellular-damage }\end{array}$ & $\begin{array}{l}\text { (c) Conjugated with Salmonella } \\
\text { DT104 specific antibody }\end{array}$ & [70] \\
\hline $\begin{array}{c}\text { Polysiloxane } \\
\text { polymers } \\
\text { containing } \\
\text { embedded } \\
\text { methylene blue and } \\
\text { AuNPs }\end{array}$ & MRSA and E. coli & $\begin{array}{l}\text { Light-induced production } \\
\text { of singlet oxygen and other } \\
\text { reactive oxygen species by } \\
\text { the methylene blue and } \\
\text { gold nanoparticles } \\
\text { enhanced activity of } \\
\text { methylene blue }\end{array}$ & $\begin{array}{l}\text { (a) Significant reduction of } \\
\text { viable cell count } \\
\text { (1) Require exposure to light and } \\
\text { polymer formation }\end{array}$ & {$[1,71,72]$} \\
\hline
\end{tabular}

\section{Host Defense Peptides (HDPs)}

The MDR infections are burgeoning at an alarming rate, and hardly any discoveries are taking place in the manufacturing of novel antibiotics to treat such stubborn bacterial infections. The seriousness of this matter creates a need for substitute strategies to treat bacterial infections. Host defense peptides (HDPs) are considered as some effective alternates that would help fight the resistant bacterial infections. These short cationic molecules are formed by the immune systems of many multicellular organisms. The evolution in nature has resulted in the formation of some remarkable HDPs, which possess diversity in structure as well as in biological activity. These natural peptides can be used as templates to generate a single 
synthetic molecule having the combined properties of antimicrobial and immunomodulatory compounds to fight the resistant bacteria when existing antibiotics fail to function. Defensins and cathelicidins are the two main families of the naturally existing HDPs [100].

Two novel peptides, brevinin1 HYba1 and brevinin1 HYba2, had been isolated from frog (Hydrophylax bahuvistara) skin secretions, and their hemolytic, cytotoxic, and antibacterial activities were investigated after designing acidic and amidated analogs. All the peptides, excluding acidic analogs, showed promising antimicrobial activity against tested Gram-positive and Gram-negative bacteria. These peptides also showed very low hemolysis on human erythrocytes. This study opened up an area to explore more natural sources of host defense peptides, which can be used as effective therapeutic agents [101].

\section{Defensins}

Defensins are cationic amphipathic peptides having approximately 30 amino acid residues. The three disulfide bonds in the structure stabilize the triple-stranded antiparallel $\beta$-sheet assembly [102]. Based on the arrangement of disulfide bonding, defensins are further divided into subfamilies: $\alpha, \beta$, and $\theta$. Among mammals, only human neutrophils and leukocyte granules possess $\alpha$-defensins [103]. In most mammals, Paneth cells of the intestines are responsible for the production of these defensins [104]. They are synthesized as precursors initially and can become activated when the $\mathrm{N}$-terminal segment is removed with the help of trypsin in humans (Figure 5). The concentration of $\alpha$-defensins reaches $10 \mathrm{mg} / \mathrm{mL}$ when they are stimulated by microbes. This concentration is enough to tackle a resilient microbial infection [100].

Bone-marrow promyelocyte

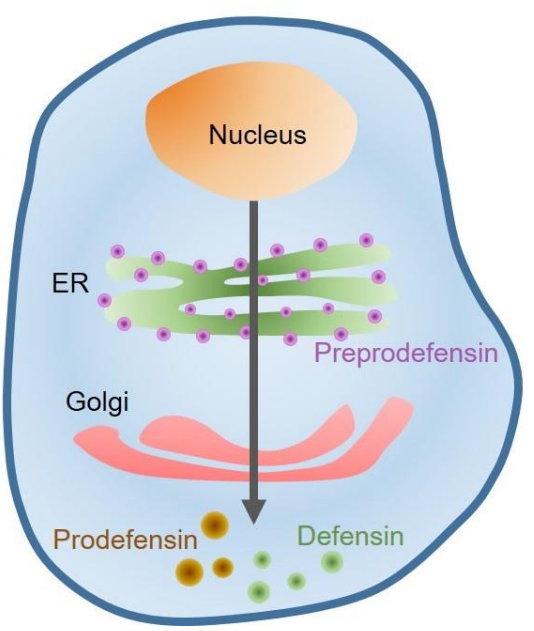

Blood neutrophil

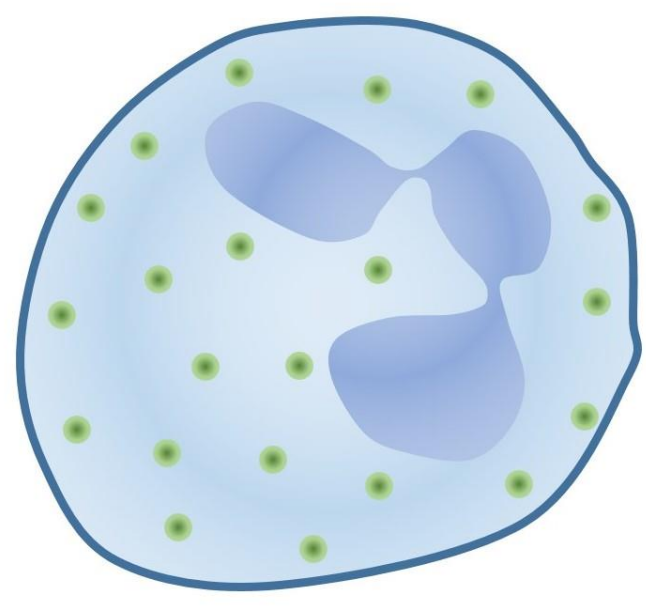

Tissue neutrophil

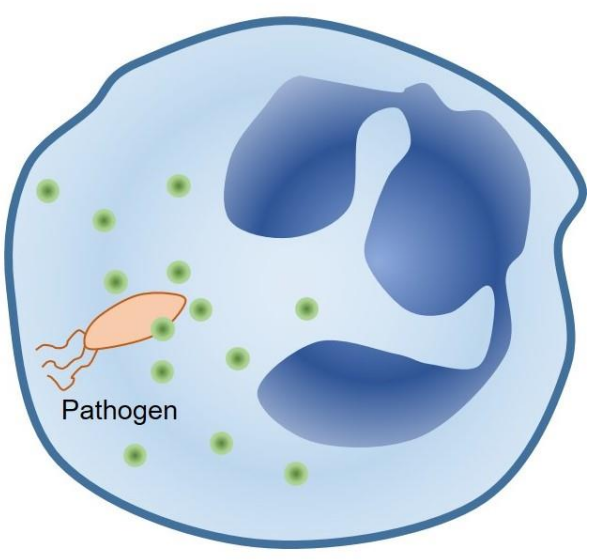

Figure 5. Promyelocytes in the bone marrow synthesize $\alpha$-defensins. 94 amino acid preprodefensin (purple) is biosynthesized in the ribosomes; the 19 amino-acid N-terminal signal sequence is cleaved and it converted to a 75 amino-acid prodefensin (brown). Subsequent cleavage of residues generates a 29-30 amino acid mature defensin (green). During phagocytosis (pathogens), defensin-rich primary granules fuse with phagocytic vacuoles and high concentrations of defensins are generated.

Most of the epithelial cells express $\beta$-defensins; proinflammatory stimuli and infections are responsible for this expression of $\beta$-defensins. They can be found in mucosal sections of gastrointestinal, respiratory, and urogenital tracts as well as in the inflamed skin [100].

The $\theta$-defensins are the rarest of all the three defensins and are cyclic molecules. Due to the cyclic structure of $\theta$-defensins, their microbicidal action is resistant to the concentration of salt. $\theta$-defensins are absent in mammals, including humans.

A variety of different defensins have also been identified in different fungi. In one study, 68 fungal defensin-like peptides (fDLPs) from five genera named Apophysomyces, Trichosporon, Scedosporium, Beauveria, and Lichtheimia had been reported. A new synthetic defensin called scedosporisin had been characterized, which shows good activity against 
Gram-positive bacteria. It killed several vancomycin-resistant Enterococci and MRSA while it showed less cytotoxicity and hemolysis. It was found out that scedosporisin-2 killed bacteria more rapidly as compared to the antibiotic vancomycin [105].

\section{Cathelicidins}

Cathelicidins are the second major group of HDPs and are categorized based on a production mechanism rather than a sequence match. The inactive precursors of cathelicidins consist of N-terminal cathelin-like domain, which is followed by a peptide region. These precursors are proteolytically cleaved to become mature and active HDPs [106]. Cathelicidins differ in sequence, length, as well as in structure. They have lengthy $\alpha$-helical and $\beta$-hairpin folds along with some short linear molecules. These short 13 amino acid molecules are the initiators for designing synthetic peptides that have optimized biological activity.

Many types of cathelicidins, such as bactenecin, indolicidin, protegrins, and many others, are produced by the immune systems of bovine and porcine [106]. The human immune system is known to produce only one type of cathelicidin precursor protein hCAP18. This precursor is processed proteolytically to produce a mature cathelicidin LL-37 [107]. Disulfide bonds are absent in LL-37. However, it adopts the conformation of $\alpha$-helical when it interacts with the lipid bilayers. Mice are known to have only one cathelicidin precursor, which is also proteolytically cleaved to produce a mature form, CRAMP. This mature peptide has a sequence identity of 67\% with LL-37 [100].

S. aureus is responsible for many serious infections in humans that sometimes lead to sepsis or death also. In one study, six novel cathelicidins named CATHPb1-6 were identified from Python bivittatu. CATHPb1 was found with an excellent pharmacological and toxicological profile In vitro. Later on, it had been observed that CATHPb1 provides efficient protection to mice against MRSA/VRSA. CATHPb1 was found to be involved in rapidly modulating macrophages/monocytes as well as trafficking the neutrophils to the site of infection and also enhance their bactericidal functions. It also increases the levels of chemokines and reduces the release of proinflammatory cytokines. Therefore, it proved to be a novel therapeutic agent against MDR S. aureus [108]. Table 2 shows HDP and their target bacteria. 
Table 2. Host defense peptides (HDP) against antibiotic-resistant bacteria.

\begin{tabular}{|c|c|c|c|c|c|c|}
\hline Category & Agent & Target Bacteria/Diseases & Mode of Action/Description & $\begin{array}{l}\text { Notes (Advantages (a), } \\
\text { Limitations (l), } \\
\text { Combination Strategy (c)) }\end{array}$ & Status & Ref \\
\hline HDP & $\begin{array}{l}\text { Brevinin } 1 \mathrm{HYba} 1 \text { and } \\
\text { brevinin1 HYba2 }\end{array}$ & $\begin{array}{l}\text { Several Gram-positive and } \\
\text { Gram-negative bacteria }\end{array}$ & $\begin{array}{l}\text { Hemolytic, cytotoxic and antibacterial } \\
\text { activities }\end{array}$ & $\begin{array}{l}\text { (a) Very low hemolysis on } \\
\text { human erythrocytes }\end{array}$ & $\begin{array}{l}\text { Hep 3B cancer cell } \\
\text { line }\end{array}$ & [101] \\
\hline \multirow[t]{2}{*}{ HDP (Defensin) } & $\begin{array}{l}68 \text { fungal defensin-like } \\
\text { peptides (fDLPs) }\end{array}$ & $\begin{array}{l}\text { A variety of bacterial, } \\
\text { fungal and viral pathogens }\end{array}$ & $\begin{array}{l}\text { (i) Cationic amphipathic peptides } \\
\text { having approximately } 30 \text { amino acid } \\
\text { residues } \\
\text { (ii) From five genera named } \\
\text { Apophysomyces, Trichosporon, } \\
\text { Scedosporium, Beauveria, and } \\
\text { Lichtheimia had been reported }\end{array}$ & $\begin{array}{l}\text { (a) Higher antibacterial } \\
\text { potential with lower cellular } \\
\text { toxicities }\end{array}$ & In vitro and in vivo & [105] \\
\hline & $\begin{array}{l}\text { Scedosporisin (synthetic } \\
\text { defensin) }\end{array}$ & $\begin{array}{l}\text { Gram-positive bacteria, } \\
\text { vancomycin-resistant } \\
\text { Enterococci, MRSA }\end{array}$ & $\begin{array}{l}\text { Scedosporisin-2 killed bacteria more } \\
\text { rapidly as compared to the antibiotic } \\
\text { vancomycin }\end{array}$ & $\begin{array}{l}\text { (a) Low cytotoxicity and } \\
\text { hemolysis on human }\end{array}$ & In vitro & [105] \\
\hline \multirow{3}{*}{ HDP (Cathelicidin) } & $\begin{array}{l}\text { Bactenecin, indolicidin, } \\
\text { protegrins, } \ldots\end{array}$ & $\begin{array}{l}\text { S. pyogenes and MRSA, } \\
\text { VISA, Listeria }\end{array}$ & $\begin{array}{l}\text { Produced by the immune systems of } \\
\text { bovine and porcine }\end{array}$ & $\begin{array}{l}\text { (a) Broad bacterial lytic } \\
\text { properties, stability and } \\
\text { higher efficacy }\end{array}$ & In vitro and in vivo & [106] \\
\hline & Human cathelicidin LL-37 & $\begin{array}{l}\text { Antibiofilm activity } \\
\text { against S. aureus and E. coli }\end{array}$ & $\begin{array}{l}\text { Human immune system is known to } \\
\text { produce only one type of cathelicidin } \\
\text { precursor protein, hCAP18 } \rightarrow \\
\text { processed proteolytically to produce } \\
\text { mature LL-37 }\end{array}$ & $\begin{array}{l}\text { (1) Exact mechanisms of } \\
\text { interaction between LL-37 } \\
\text { and immune cells have not } \\
\text { been yet clarified }\end{array}$ & In vitro and in vivo & [107] \\
\hline & $\begin{array}{l}\text { CATHPb1-6 (six novel } \\
\text { cathelicidins identified } \\
\text { from Python bivittatu) }\end{array}$ & S. aureus (MRSA/VRSA) & $\begin{array}{c}\text { Involved in modulating } \\
\text { macrophages/monocytes; } \\
\text { trafficking neutrophils to the site of } \\
\text { infection and also enhance their } \\
\text { bactericidal functions; increases levels } \\
\text { of chemokines and reduces release of } \\
\text { proinflammatory cytokines }\end{array}$ & $\begin{array}{l}\text { (a) Provides protection via } \\
\text { different administration } \\
\text { routes }\end{array}$ & $\begin{array}{l}\text { In vitro and in vivo } \\
\text { (mice) }\end{array}$ & [108] \\
\hline
\end{tabular}




\section{Antimicrobial Peptides (AMP)}

Antimicrobial peptides (AMP) are evolutionarily conserved macromolecules produced by most living organisms ranging from prokaryotes to humans as a first line of defense. AMP are a part of innate immune response and have an ability to fight against pathogenic microbes. These small peptides ranging from 05 to 100 amino acid residues are generally cationic in nature and are folded into unique structures that facilitate their mode of action. AMP help to eradicate (pathogenic) bacteria either by killing them directly or by modulating the host immune response. They can be used against a number of microbes and have proven to be a promising agent when used as antibacterial either alone or in combination with other methods [102,106,109].

Antimicrobial photodynamic therapy is one of the novel approaches, which, in combination with antimicrobial peptides, has a great potential to act as a favorable tool against MDR bacteria. Photodynamic therapy is quite effective against Gram-positive bacteria, but combinational therapy with AMP makes it potent against Gram-negative too. Photodynamic AMP generate reactive oxygen species upon exposure to light of a certain wavelength and disrupt the cell wall and membrane resulting in cell death [110].

Biofilms are three-dimensional multicellular structures that form on natural and/or clinical surfaces. Biofilms are adaptively resistant to antibiotics, due to which they are difficult to treat as compared to their planktonic forms [111]. They are formed on various implanted devices, and these aggregates can only be removed by surgery [112]. Therefore, it is very challenging to treat biofilm-related infections; there is an urgent need for new therapeutic options to fight them out. In recent years, various approaches had been developed, such as bacteriophages, antibodies, quorum sensing antagonism, etc. One of the most promising approaches is the use of antibiofilm peptides (ABP), which are a class of the AMP; these proteinaceous entities can either be cationic or amphipathic [113] and are a part of the host defense peptides. The first-ever cationic peptide, nisin, was isolated in 1928 from Lactobacillus lactis. It was relatively stable at room temperature, but at $\mathrm{pH} 2-6$, it showed high antimicrobial activity $[114,115]$. Natural AMP polylysine was isolated from Streptomyces albulus 346 and is now commercially produced for a variety of food applications as preservative agents [116]. ABP shows activity against a variety of resistant Gram-positive and Gram-negative bacterial strains. They are also found to be very effective against fungal microbes. Interactions of these peptides with bacterial components do not require any specific protein binding sites, and it is why they would theoretically not have any resistance emerged against them [109]. Recently, they have been put to work in many applications, including oral candidiasis, catheter-associated, and implant surface infections $[117,118]$. The human cathelicidin peptide LL-37 was shown to exhibit antibiofilm activity against $S$. aureus and E. coli [119]. The two tryptophan-rich cationic AMP KT2 and RT2 were found to show antibiofilm activity against enterohemorrhagic E. coli O157:H7, which is a multidrug-resistant strain. These two peptides did not only prevent the biofilm formation but also could eliminate mature biofilms [120]. It has also been reported that these peptides can be used in conjugation with other antimicrobial compounds to enhance their activity (synergistic effects) [121]. This synergy helps in lowering the concentration of antimicrobial compounds, which will, in turn, reduce the (toxic) side effects of these compounds and stop the spread of antimicrobial resistance [122]. Most commonly, these peptides permeabilize bacterial cell membranes, which lead to the death of cells either by causing large damage or small obstructions that will, in turn, disturb transmembrane potential leading to cell death [123]. Specifically, their mechanism of action has been explained by pore and non-pore models. For pore models, there are two theories; the toroidal pore model, in which antimicrobial peptides can affect the curvature of membrane and the barrel stave pore model, in which these will interact with the cell membrane and form a hydrophilic pore [124,125]. For non-pore models, there are many theories, such as the detergent model, the molecular shape model, and the carpet model [126]. Among these, the carpet model is the most common model. According to this model, peptide monomers form a layer on the surface of the membrane, which leads to 
the destabilization of a phospholipid bilayer, which then results in the breakdown of the membrane [127]. Much research has been carried out to develop antimicrobial peptides as effective antimicrobials, but hurdles are there because these have complex interactions with membranes as well as with each other. Very limited data are available on such peptides having antibiofilm properties. Therefore, more work is needed to be done to understand the proper mechanism of action [128]. However, we have shown various possible ways ABPs can get over a superbug and kill it when it resists antibiotic drugs in Figure 6.

$\mathrm{ABP}$ can also be obtained from the poisons of various animals like ants, wasps, bees, scorpions, and spiders. One such peptide, called Mastoparan peptide, isolated from Vespidae venom showed broad-spectrum antimicrobial activity against both Gram-positive and Gram-negative bacteria, Mycobacteria and fungi. In one study, two peptides, agelaia-MPI and polybia-MPII, isolated from wasps, showed bactericidal activity along with antibiofilm activity against biofilm-forming MDR Acinetobacter baumannii [129]. Five ocellatin peptides, ocellatin-PT2-PT6, had been isolated from frog Leptodactylus pustulatus skin secretion and used against an MDR opportunistic pathogen, P. aeruginosa, where they effectively killed the bacterial pathogen. Another ocellatin peptide, named ocellatin-PT3, inhibits the proliferation of established biofilms by direct killing of bacterial cells within biofilm [130].

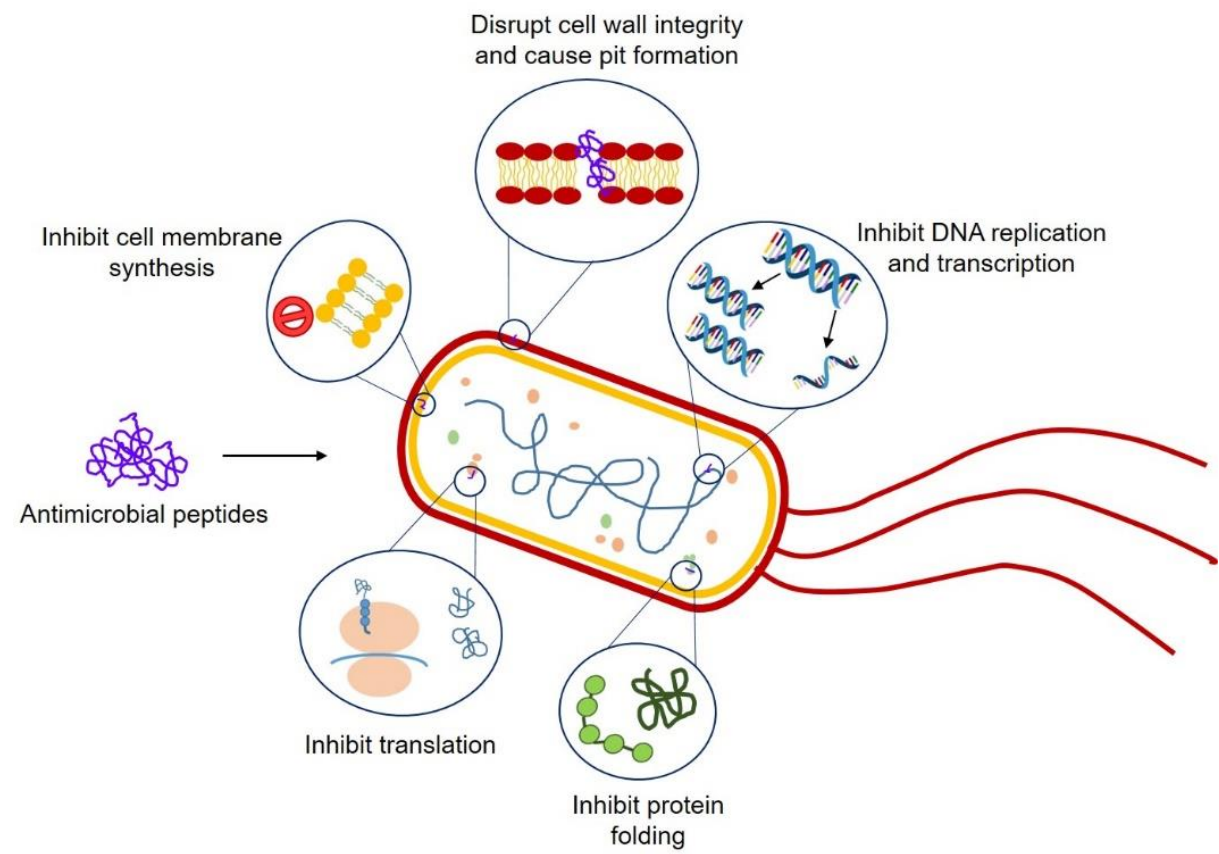

Figure 6. Possible mechanisms antimicrobial peptides can kill bacterial superbugs.

The EPS of some bacterial species like non-typeable H. influenza, S. enterica serovar Typhimurium/Typhi and P. aeruginosa are responsible for the resistance against innate immune components, including AMP. This resistance is particularly due to the structure of the biofilm community. The polysaccharides and extracellular DNA (eDNA) of EPS bind the AMPs because of charge differences [131]. There are specific sensors in bacteria that are responsible for activating the resistance mechanisms against AMP upon exposure [132,133]. It had been demonstrated that in P. aeruginosa, the $p s r A$ gene encodes a transcriptional regulator which upregulates in response to the presence of subinhibitory concentrations of cationic AMP [134]. Table 3 describes possible mode(s) of action of (AMP) ABP with their advantages and limitations. 
Table 3. A list of different antimicrobial peptides (AMP) (antibiofilm peptides (ABP)) molecules that can be used against multidrug-resistant (pathogenic) bacteria.

\begin{tabular}{|c|c|c|c|c|c|c|}
\hline Category & Agent & Target Bacteria/Diseases & Mode of Action/Description & $\begin{array}{c}\text { Notes (Advantages (a), Limitations (1), } \\
\text { Combination Strategy (c)) }\end{array}$ & Status & Ref. \\
\hline $\mathrm{ABP}$ & Nisin & Variety of Gram-positive & Cationic peptide & (1) Requires proper optimization of $\mathrm{pH}$ & In vitro & [114] \\
\hline $\mathrm{ABP}+\mathrm{HDP}$ & $\begin{array}{l}\text { Combination of peptides } \\
\text { and defensin proteins }\end{array}$ & $\begin{array}{c}\text { Variety of Gram-positive and } \\
\text { Gram-negative bacteria; effective } \\
\text { against fungi too }\end{array}$ & $\begin{array}{l}\text { Proteinaceous entities can either } \\
\text { be cationic or amphipathic }\end{array}$ & $\begin{array}{c}\text { (a) Not require any specific protein } \\
\text { binding sites }\end{array}$ & In vitro & [113] \\
\hline \multirow{3}{*}{$\mathrm{ABP}$} & $\begin{array}{l}\text { Antimicrobial peptides } \\
\text { KT2 and RT2 }\end{array}$ & $\begin{array}{c}\text { Antibiofilm activity against MDR } \\
\text { enterohemorrhagic E. coli } \\
\text { O157:H7 }\end{array}$ & $\begin{array}{l}\text { Tryptophan-rich cationic } \\
\text { peptides permeabilize bacterial } \\
\text { cell membranes } \rightarrow \text { lead to death } \\
\text { of cells by causing large damage } \\
\text { or small obstructions that disturb } \\
\text { transmembrane potential }\end{array}$ & $\begin{array}{l}\text { (a) Not only prevent biofilm formation } \\
\text { but also can eliminate mature biofilms } \\
\text { (l) Interactions with membrane and } \\
\text { each other } \\
\text { (c) Combination with other } \\
\text { antimicrobial compounds to enhance } \\
\text { activity } \rightarrow \text { lower concentration of } \\
\text { antimicrobial compounds }\end{array}$ & In vivo & {$[100,120]$} \\
\hline & $\begin{array}{l}\text { Agelaia-MPI and } \\
\text { Polybia-MPII }\end{array}$ & $\begin{array}{l}\text { MDR Acinetobacter baumannii, } \\
\text { several Gram-positive and } \\
\text { Gram-negative bacteria, } \\
\text { Mycobacteria as well as fungi }\end{array}$ & $\begin{array}{l}\text { Isolated from wasps; bactericidal } \\
\text { activity along with antibiofilm } \\
\text { activity }\end{array}$ & $\begin{array}{l}\text { (l) Production costs } \\
\text { (l) Peptidases and proteases lead to low } \\
\text { stability of peptides in human serum } \rightarrow \\
\text { (c) Increased stability in combination } \\
\text { with other molecules (e.g., polyethylene } \\
\text { glycol) }\end{array}$ & In vitro & [129] \\
\hline & Ocellatin-PT2-PT6 & $\begin{array}{l}\text { Opportunistic pathogen } \\
\text { Pseudomonas aeruginosa }\end{array}$ & $\begin{array}{c}\text { Ocellatin-PT3 inhibits } \\
\text { proliferation of established } \\
\text { biofilms by directly killing } \\
\text { bacterial cells }\end{array}$ & $\begin{array}{l}\text { (a) Novel antimicrobial agent(l) Works } \\
\text { better in combination BS antibiotics }\end{array}$ & in vitro & [130] \\
\hline $\mathrm{QS}+\mathrm{ABP}$ & $\begin{array}{l}\text { "RNAIII-inhibiting } \\
\text { peptide" (RIP) }\end{array}$ & $\begin{array}{l}\text { Biofilm formation and ailments } \\
\text { caused by S. aureus }\end{array}$ & $\begin{array}{l}\text { Inhibition of phosphorylation of } \\
\text { "target of RNAIII activating } \\
\text { protein" } \rightarrow \text { quorum sensing } \\
\text { inhibition, prevention of MDR in } \\
\text { bacteria }\end{array}$ & $\begin{array}{l}\text { (a) Inhibits cell adhesion and biofilm } \\
\text { formation }\end{array}$ & $\begin{array}{l}\text { In vitro and } \\
\text { in vivo } \\
\text { (cellulitis) }\end{array}$ & {$[135,136]$} \\
\hline
\end{tabular}




\section{Bacteriophage Therapy}

Bacteriophages are diverse non-living biological entities that consist of DNA or RNA surrounded by a protein capsid. They are capable of reproducing independently and are ultimately dependent on bacterial hosts for survival. Phages normally bind themselves to specific receptors on the bacterial cell surface, release their genetic material into the host cell and then either incorporate this material into the bacterial genome and reproduce vertically from mother to daughter cells or invade the bacterial replication mechanism to produce the next-generation of phage offspring and lyse the cell. When a critical mass of phage offspring is reached, which can be from a few to over 1000 viral particles, depending on environmental factors, the lytic proteins are activated and hydrolyze the peptidoglycan (cell wall) of bacteria [137]. Scientists suggested that phages can be used as suitable antibiotic agents with having maximum efficiency.

Treatment of infectious diseases is becoming difficult and a threat to mankind due to a rise in antibiotic-resistant microbial strains [19]. To prevent and treat such resistant strains, phage therapy is becoming popular and gaining interest all over the world [138,139]. Pioneering (novel) antimicrobial approaches using phage products, or genetically manipulated phages, are being exploited to cope with bacterial infections and antibiotic resistance (Figure 7) [139]. Phages infect bacterial cells and produce endolysins that damage the bacterial cell wall by hydrolyzing the four main bonds of its peptidoglycan constituent in the lytic cycle $[138,140,141]$. An osmotic imbalance is the cause of lysis when the cell losses structural integrity upon peptidoglycan degradation. In the case of Gram-negative bacteria, the outer membrane is ruptured with the help of complexes (spanins), fusing both the inner and the outer membrane [139].
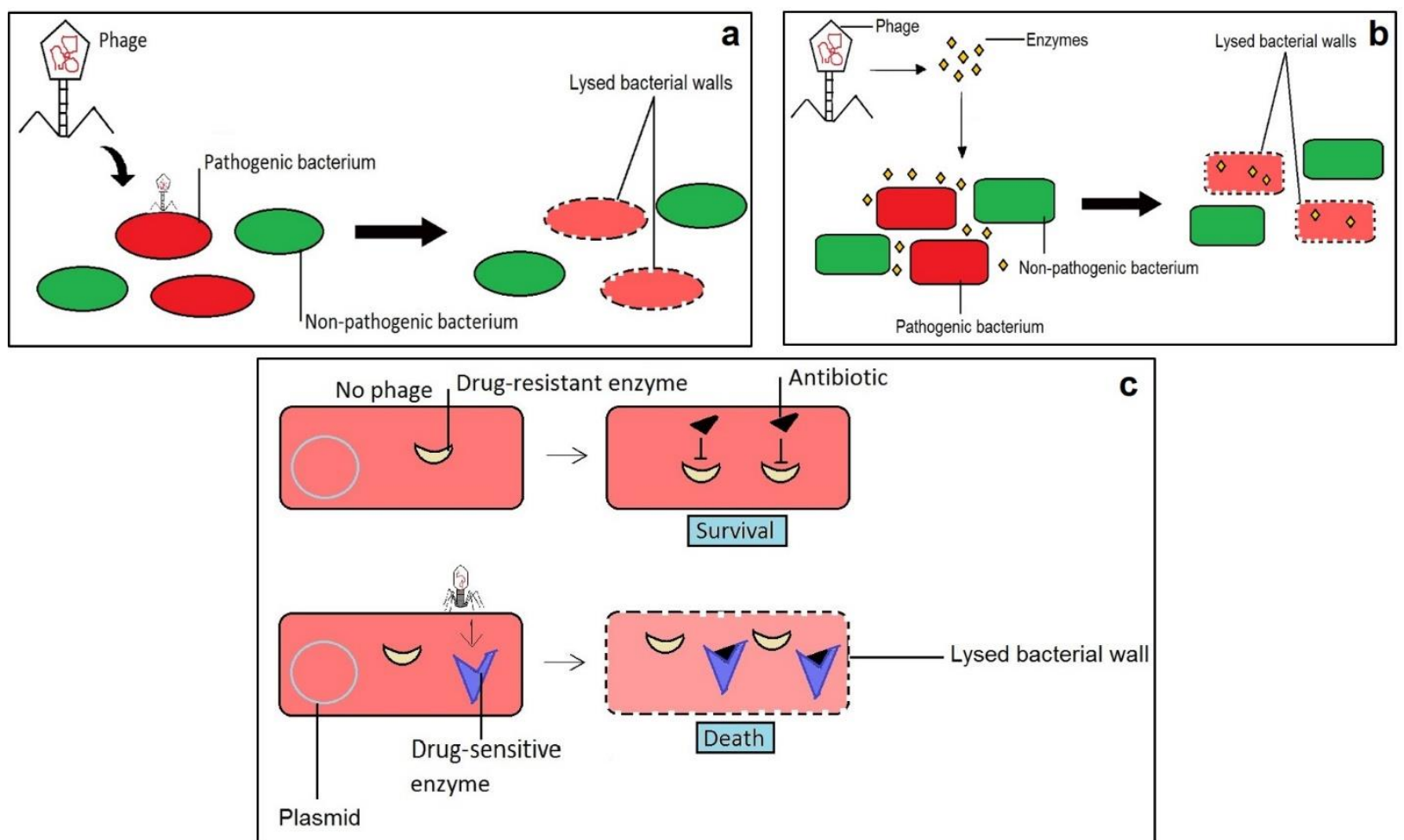

Figure 7. Phage-derived antimicrobial techniques. Novel antimicrobial strategies derived from phages and their products. (a) Phages target specific bacterial pathogens and thus cause the lysis of that particular bacterial cell wall; (b) phages produce enzymes that target particular bacterial pathogens; (c) phages can be used to transfer antibiotic-sensitive genes into drug-resistant bacteria.

Bacteriophages have been successfully used against bacterial biofilms, in therapeutics (genetically modified form), in the food industry to minimize the bacterial load and to im- 
prove antibiotic potency (Figure 7c) [138,142]. Antibiotics delivered along with the phages permit delivery to specific cells and can cause an upsurge in local drug concentrations [139].

Bacteriophages are used both externally and internally to treat diseases that could otherwise not be cured by antibiotics [138]. For example, in a study, phage application significantly decreased the concentration of bacterial cells (in all patients' sputum samples), improving overall health. Birds had also been reported to have a reduction in a load of Salmonella and Campylobacter in the poultry meat when a multivalent/cocktail of lytic bacteriophages was used to help the meat industry to produce safe and good quality edible products $[138,143]$.

Bacteriophages have several advantages over antibiotics, i.e., they have an affinity for a specific bacterium, which helps in typing of that particular bacterium and causes its lysis, whereas using the (broad-spectrum) antibiotics would also harm the normal flora. Due to their replicative nature, there is no need to administer the bacteriophages repeatedly, and Most of the phages can be ingested as they can survive in the gastric environment $[140,144]$ and are even lethal to MDR bacterial superbugs: E. faecalis, S. aureus, Klebsiella, A. baumannii, P. aeruginosa, and Escherichia coli [19]. Because of minimal side effects, they are also considered to be ecologically safe (i.e., harmless to humans, plants, and animals) $[19,138,145]$.

However, the disadvantages of phage therapies must not be overlooked either. In the case of mixed infections, phages are not very effective due to their narrow host range, whereas broad-spectrum antibiotics work effectively in similar scenarios [138,146]. If the selected phage switches to the lysogenic life cycle, it will integrate its genome in the host cell leading to failure in phage therapy. Moreover, if phages are not sequenced before their administration in humans or animals, they may carry a toxic (deleterious) gene that can be harmful [138]. We should always use a cocktail of phages so that the risk of resistance development could be reversed or diminished $[19,147]$.

The frequency of bacterial resistance to phages is significantly lower $\left(10^{-7}\right.$ to $10^{-8}$ per cell) compared with that of the resistance to antibiotics (frequency of mutation for one specific gene is $10^{-5}$ per cell). Bacterial cells can also become resistant to phages as their cell receptors are specific to different phages; constructing the "suitable" cocktail will help to achieve the maximum effectiveness of phage therapy [19].

Recent investigations using animal models have explored phage treatments against different bacteria, which have shown positive results. When challenged with gut-derived sepsis due to $P$. aeruginosa, oral administration of phages saved $66.7 \%$ of mice from mortality in comparison to $0 \%$ in the control group. In a hamster model of Clostridium difficile-induced ileocolitis, a single dose of phage synchronized with $C$. difficile administration was sufficient as prophylaxis against the infection; phage treatment post-infection saved 11 of 12 mice, whereas control animals administered with C. difficile and clindamycin died within 96 h [148].

Phage combinations also lowered $C$. difficile growth significantly in in vitro and limited proliferation in vivo using a hamster model [149]. Intraperitoneal administration of a single phage strain was effective to rescue $100 \%$ of mice in bacteremia models using vancomycinresistant E. faecium [150], extended-spectrum $\beta$-lactamase producing E. coli [151], and imipenem-resistant $P$. aeruginosa [152].

Phage cocktails can be utilized in treating antibiotic-resistant $P$. aeruginosa infections of the skin, lungs, and gastrointestinal tract in animal models [153,154]. Reports also suggest that phages have the potential to restore sensitivity in antibiotic-resistant bacteria like the case of multidrug-resistant $P$. aeruginosa. Phages are combatting antibiotic-resistant bacteria by limiting their capacity to evolve resistance $[155,156]$.

Unlike antibiotics, phages may evolve novel counter-defense mechanisms to counter bacterial resistance at a rate that can never be replicated by researchers developing antibiotics [157-160].

A. baumannii is a nosocomial pathogen that is rapidly evolving resistance against antibiotics. Two novel bacteriophages, named PBAB08 and PBAB25, were used against the MDR A. baumannii in a mouse model. Mice treated with a phage cocktail showed a 2.3-fold 
more survival rate along with a 1/100 reduction of the total number of $\mathrm{A}$. baumannii in the lungs [161]. A person infected with MDR A. baumannii was treated with bacteriophages, and the patient was reported to be more alert than before, his craniotomy site and skin flap healed very well. He had lost all the symptoms of the infection and got healthy [162]. These findings suggested that the newly isolated phages could be used as effective therapeutic candidates against (MDR) A. baumannii.

Phage lysins are solely capable of lysing bacterial cells, and they have been identified as potential antimicrobial agents. These proteins are efficient, potent, and inactive against eukaryotic cells. Mice have been successfully saved from bacteremia through lysins caused by MDR A. baumannii [163], Streptococcus [164], and MRSA [165].

Using phage lysins and antibiotics in amalgamation may prove more effective at eradicating infections than by using antibiotics solely, as displayed in vitro and in vivo in a colon model using C. difficile [166]. All lysins do not show equal therapeutic potential, however as highlighted in an article [167], a highly potent lysin, PlySs2, was identified, which proved very effective against several pathogenic Streptococcus and Staphylococcus species, such as MRSA, and remained fully operational even after 10 freeze-\&-thaw cycles. A recent study about the isolation and application of phage proteins has shown that lysins can cross the epithelial cell membrane to eradicate intracellular infections of $S$. pyogenes [168]. Phage lysins also interrupt vegetative cells, as displayed with B. anthracis lysin PlyG, which has the potential of attacking endospores of Bacillus, a major advantage over antibiotics. Table 4 enlists and summarizes different phages and phage cocktails used against resistant bacteria. 
Table 4. Bacteriophages as a therapeutic option against bacteria.

\begin{tabular}{|c|c|c|c|c|c|}
\hline Agent & Target Bacteria/Diseases & Mode of Action/Description & $\begin{array}{c}\text { Notes (Advantages (a), Limitations (l), } \\
\text { Combination Strategy (c)) }\end{array}$ & Status & Ref \\
\hline \multicolumn{6}{|c|}{ Bacteriophages } \\
\hline $\begin{array}{l}\phi \mathrm{MR} 11, \mathrm{KP} \text { DP1, SA } \\
\text { DP1, PA DP4, EC DP3 }\end{array}$ & $\begin{array}{c}\text { E. faecalis, S. aureus, Klebsiella, } A \text {. } \\
\text { baumannii, P. aeruginosa, and } \\
\text { Escherichia coli }\end{array}$ & $\begin{array}{l}\text { Phages bind to specific receptors on bacterial } \\
\text { cell surface } \rightarrow \text { infects bacterial cells } \rightarrow \\
\text { production of endolysins that damage } \\
\text { bacterial cell wall by hydrolyzing four main } \\
\text { bonds of peptidoglycan, } \\
\text { Rupture of outer membrane via complexes } \\
\text { (spanins) (Gram-negative bacteria) }\end{array}$ & $\begin{array}{c}\text { (a) Applied externally and internally; } \\
\text { high affinity for specific bacterium (normal } \\
\text { flora not attacked) } \\
\text { only one administration (replicative nature); } \\
\text { can survive in the gastric environment; } \\
\text { minimal side effects } \rightarrow \text { ecologically safe; } \\
\text { frequency of bacterial resistance to phages } \\
\text { significantly lower compared with resistance } \\
\text { to antibiotics } \\
\text { (l) Not very effective in mixed infections } \\
\text { (narrow host range) }\end{array}$ & In vivo (mice) & {$[19,169]$} \\
\hline $\begin{array}{l}\text { Lytic phage strain } \\
\text { (KPP10) }\end{array}$ & P. aeruginosa & $\begin{array}{c}\text { Decreased numbers of viable P. aeruginosa } \\
\text { cells in blood, liver, and spleen as well as } \\
\text { levels of inflammatory cytokines in blood } \\
\text { and liver }\end{array}$ & (c) Oral administration & Animal models & [153] \\
\hline CD140 & $\begin{array}{l}\text { Clostridium difficile-induced } \\
\text { ileocolitis }\end{array}$ & $\begin{array}{l}\text { Phage administration prophylaxis against } \\
\text { infection }\end{array}$ & (1) Specific against Clostridium difficile & hamster & [148] \\
\hline $\begin{array}{l}\text { ØCDHM1-ØCDHM6, } \\
\text { ØCDHS1, ENB6 and } \\
\text { C33, Ø9882, } \\
\text { ØA392, and } \\
\text { KPP10 }\end{array}$ & $\begin{array}{c}\text { Clostridium difficile, } \\
\text { vancomycin-resistant } E \text {. faecium, } \\
\text { extended-spectrum } \\
\beta \text {-lactamase producing } E \text {. coli, } \\
\text { imipenem-resistant and MDR } P . \\
\text { aeruginosa }\end{array}$ & Treatment of gut-derived sepsis & $\begin{array}{l}\text { (a) Specifically act against bacterial } \\
\text { pathogens } \\
\text { (a) Do not affect the natural bioflora } \\
\text { (a) Safer to use in humans } \\
\text { (1) They will be effective only if their } \\
\text { favorable conditions exist }\end{array}$ & $\begin{array}{l}\text { Hamsters and } \\
\text { mice }\end{array}$ & {$[150,154]$} \\
\hline OMKO1 & MDR $P$. aeruginosa & $\begin{array}{l}\text { Outer membrane porin } \mathrm{M}(\mathrm{OprM}) \text { of the } \\
\text { multidrug efflux systems MexAB and } \\
\text { MexXY as a receptor-binding site }\end{array}$ & $\begin{array}{l}\text { (a) Specifically act against MDR P. aeruginosa } \\
\text { (a) Alters efflux pump mechanism to make } \\
\text { the bacterium more susceptible to drugs }\end{array}$ & In vitro & [154] \\
\hline PBAB08 and PBAB25 & Acinetobacter baumannii & $\begin{array}{l}\text { Reduction of bacterial load, increase in } \\
\text { serum IgE with a slight increase of GM-CSF, } \\
\text { IL2, IL10, and IL17A }\end{array}$ & $\begin{array}{l}\text { (1) Inoculated in a cocktail and require } \\
\text { properly set optimal conditions }\end{array}$ & mouse & [163] \\
\hline Mixture of three phages & Campylobacter jejuni and C. coli & Reduce bacterial colonization & (1) Acquisition phage to resistance & Poultry & [143] \\
\hline
\end{tabular}


Table 4. Cont.

\begin{tabular}{|c|c|c|c|c|c|}
\hline Agent & Target Bacteria/Diseases & Mode of Action/Description & $\begin{array}{l}\text { Notes (Advantages (a), Limitations (1), } \\
\text { Combination Strategy (c)) }\end{array}$ & Status & Ref \\
\hline PlyF307 (phage lysin) & MDR A. baumannii & Lysing of bacterial cells & (a) Inactive against eukaryotic cells & Mouse & [163] \\
\hline Cpl-1 (phage endolysin) & Streptococcus pneumoniae & $\begin{array}{l}\text { Reduced pulmonary bacterial counts and } \\
\text { prevented bacteremia, systemic hypotension, } \\
\text { and lactate increase as well as reduction of } \\
\text { penicillin-susceptible pneumococci }\end{array}$ & (1) Specific against pneumococci & Mouse & [164] \\
\hline $\begin{array}{l}\text { PGHs (phage } \\
\text { endolysins) }\end{array}$ & MRSA & $\begin{array}{l}\text { The peptidoglycan hydrolase enzyme } \\
\text { targets the conserved regions and can } \\
\text { destroy a wide range of mutant cell walls of } \\
\text { bacteria }\end{array}$ & $\begin{array}{l}\text { (a) Active against mutant and resistant } \\
\text { strains } \\
\text { (a) Also can clear static biofilms }\end{array}$ & $\begin{array}{l}\text { In vitro and in } \\
\text { Mouse }\end{array}$ & [165] \\
\hline PlyCD (prophage lysin) & C. difficile & $\begin{array}{l}\text { PlyCD specifically targets the pathogenic } C \text {. } \\
\text { difficile while not affecting other commensal } \\
\text { bacteria }\end{array}$ & $\begin{array}{c}\text { (c) Phage lysins in combination with } \\
\text { antibiotics more effective than antibiotics } \\
\text { alone }\end{array}$ & $\begin{array}{l}\text { Ex vivo mouse } \\
\text { colon model }\end{array}$ & [166] \\
\hline $\begin{array}{l}\text { PlySs2 (phage } \\
\text { endolysin) }\end{array}$ & $\begin{array}{l}\text { Streptococcus and Staphylococcus } \\
\text { species, such as MRSA }\end{array}$ & Lytic activity & $\begin{array}{l}\text { (a) High therapeutic potential compared to } \\
\text { other lysins }\end{array}$ & Mouse & [167] \\
\hline PlyC (phage endolysin) & S. pyogenes & $\begin{array}{l}\text { Lysins can cross the epithelial cell membrane } \\
\text { to eradicate intracellular infections }\end{array}$ & (a) Ability to traverse epithelial membranes & model membranes & [168] \\
\hline PlyG (phage endolysin) & Bacillus anthracis & $\begin{array}{l}\text { Interrupt vegetative cells; major advantage } \\
\text { over antibiotics (attacking endospores) }\end{array}$ & $\begin{array}{l}\text { (a) Separate domains to recognize spores } \\
\text { and vegetative cells }\end{array}$ & In vitro & [170] \\
\hline
\end{tabular}




\section{Immune Stimulation via Bacterial Extracts}

Bacteria and bacterial extracts have been used for immunotherapy for several years. Recently, it has been discovered that these nonspecific immune activators trigger specific receptors of immune cells (and certain molecular signaling pathways); opened a new era of targeted immunotherapy. It can be achieved by using chemically synthesized molecules mimicking specific pathogen molecules. Bacterial extracts contain specifically and nonspecifically stimulating agents that activate innate and the adaptive immune system [171]. For the treatment of complicated as well as (other) infections that are caused by resistant strains, bacterial extracts can be used as adjuvants [172]. Bacterial extracts can activate macrophages and monocytes due to the presence of bacterial wall structures, like lipopolysaccharide or proteoglycans, which interact with Toll-like receptors (TLR) that are expressed over the surface of monocytes. Due to this interaction, monocytes are activated; they will differentiate into immature dendritic cells and then mature into dendritic cells, which are considered as suitable antigen-presenting cells, and the activation of this mechanism would cause a stimulation of the immune response. The antigen presentation over mature dendritic cells, in turn, stimulates $\mathrm{T}$ helper and B lymphocytes, following the maturation into plasma cells along with antibody production. These antibodies then cause bacterial opsonization, followed by destruction via macrophages [173].

Lipopolysaccharide (LPS) is a well-known virulence factor of bacteria that stimulates an innate immune response in hosts. In one study, LPS was extracted from the highly resistant isolates of Proteus mirabilis and incorporated into a liposomal delivery system. It was injected in rats via the intraperitoneal route, and its efficiency in stimulating immune responses was weighed by determining the Toll-like receptors and CD14 levels. The results showed that liposomes having incorporated LPS could release moderate levels of Toll-like receptors-4 (TLR4) that, in turn, enabled the immune system to clear pathogens [174].

\section{Vaccination}

Vaccination had been so fruitful in the world of multidrug resistance owing to its mechanism of action that diminishes the burden of the disease, thereby reducing the use of antibiotics and thus culminating the basis of MDR evolution. Since antibiotics are not being utilized (in this case), the resistance cannot develop, and selection cannot occur; neither of the pathogen at hand nor the "bystander" species present $[175,176]$. The vaccination process can considerably influence the MDR better if herd immunity is conferred [175,177], that is, protection of unvaccinated population by the vaccinated population such that they act as buffers, not being affected by the disease themselves and thereby reducing the chance of transmission to others. Moreover, for vaccines against bacteria like S. pneumoniae, S. aureus, and members of the family Enterobacteriaceae, which inhabit the nasopharynx, skin, gastrointestinal tract; there is the hypothetical likelihood that plummeting the density of bacterial populations by vaccination diminishes the prospects for genetic reassortment and recombination of resistant genes $[175,178,179]$. Vaccines that are generated specifically against virulence factors can be very powerful because these days, there are numerous genomic sequences available for almost all species. The state-of-the-art technologies and methods, such as reverse vaccinology, which can filter out the best models, are suited for enhanced immune responses. Some vaccines that are currently under production directing the aim towards virulence factors: (i) a tetra-subunit vaccine comprising of two capsular polysaccharides and two virulence-associated proteins (ClfA and MntC) against $S$. aureus, which is presently in phase $2 b$ trials $[175,180]$, (ii) three vaccines against C. difficile constructed on toxins A and B which are in phase 2 and 3 trials [181], (iii) a vaccine against $P$. aeruginosa founded on conserved outer membrane protein $\mathrm{F} / \mathrm{I}$ fusion which is in phase $2 / 3$ trials in an intensive care unit (ICU) patients $[175,182]$, and (iv) a vaccine for Candida targeting T cell target protein, Als3 [175,183,184] is in the phase 2 trials. In recent times, it has been anticipated that directing vaccines against already resistant strains or even against resistance determinants themselves may be an actual way to thwart the selection pressure for antimicrobial resistance $[23,175,185]$. Antiresistance 
vaccines ought to be more operational against the drug-resistant strains in comparison to drug-susceptible ones by explicitly targeting resistant alleles of a conserved protein (for instance, a neuraminidase binding protein in the influenza virus) or by targeting proteins exclusively present in resistant clusters (such as ribosomal methylases deliberating macrolide resistance). Two vaccines are being developed under the shadow of this theory; that is, the resistance causing elements can be the foundation of vaccines providing a strong immune response. Protection against MRSA [175,182,186,187] can be sought through a vaccine that aims for the resistance-conferring extra penicillin-binding protein (PBP2a), while in Neisseria meningitidis, the target would be one of the essential penicillin-binding proteins $[175,188]$. The use of a variety of vaccines that may provide immunity against infectious agents is summarized in Table 5 .

Table 5. Different types of vaccines used to fight the bacterial multidrug resistance.

\begin{tabular}{|c|c|c|c|c|c|}
\hline Agent & $\begin{array}{c}\text { Target } \\
\text { Bacteria/Diseases }\end{array}$ & $\begin{array}{c}\text { Mode of } \\
\text { Action/Description }\end{array}$ & $\begin{array}{l}\text { Notes (Advantages (a), } \\
\text { Limitations (l), } \\
\text { Combination Strategy } \\
\text { (c)) }\end{array}$ & $\begin{array}{l}\text { In Vitro, In Vivo, } \\
\text { Clinical Phase, } \\
\text { Animal Model }\end{array}$ & Ref \\
\hline \multicolumn{6}{|c|}{ Vaccines } \\
\hline $\begin{array}{l}\text { Tetra-subunit } \\
\text { vaccine }\end{array}$ & S. aureus & $\begin{array}{l}\text { Comprising of two } \\
\text { capsular } \\
\text { polysaccharides and two } \\
\text { virulence-associated } \\
\text { proteins (ClfA and } \\
\text { MntC) }\end{array}$ & $\begin{array}{l}\text { (c) Diminish the burden of } \\
\text { the disease, thereby } \\
\text { reducing use of antibiotics }\end{array}$ & Phase $2 b$ trial & [175] \\
\hline $\begin{array}{l}\text { Three different } \\
\text { vaccines }\end{array}$ & C. difficile & $\begin{array}{l}\text { Constructed on } C \text {. } \\
\text { difficile toxins } \mathrm{A} \text { and } \mathrm{B}\end{array}$ & $\begin{array}{l}\text { (1) More research is } \\
\text { required for proper } \\
\text { optimizations of } \\
\text { toxin-based vaccines, } \\
\text { including development } \\
\text { and use of novel adjuvants }\end{array}$ & Phase 2 and 3 trials & [189] \\
\hline $\begin{array}{l}\text { OprF/I fusion } \\
\text { protein vaccine }\end{array}$ & P. aeruginosa & $\begin{array}{l}\text { Founded on conserved } \\
\text { outer membrane protein } \\
\text { F/I fusion }\end{array}$ & $\begin{array}{l}\text { (a) Produce rapid immune } \\
\text { response in healthy } \\
\text { volunteers }\end{array}$ & Phase $2 / 3$ trials & {$[175,190]$} \\
\hline Vaccine NDV-3 & Candida & $\begin{array}{l}\text { Targeting T cell target } \\
\text { protein, Als3 }\end{array}$ & $\begin{array}{l}\text { (a) Also protects from } \\
\text { intravenous as well as skin } \\
\text { and soft tissue infection } \\
\text { with Staphylococcus aureus }\end{array}$ & Phase 2 trials & [184] \\
\hline $\begin{array}{l}\text { Antiresistance } \\
\text { vaccines }\end{array}$ & MRSA & $\begin{array}{l}\text { Cloned internal region } \\
\text { from transpeptidase } \\
\text { domain from } \\
\text { penicillin-binding } \\
\text { protein (PBP2a) as DNA } \\
\text { vaccine }\end{array}$ & $\begin{array}{l}\text { (a) More operational } \\
\text { against drug-resistant } \\
\text { strains by explicitly } \\
\text { targeting resistant alleles } \\
\text { of a conserved protein or } \\
\text { by targeting proteins } \\
\text { exclusively present in } \\
\text { resistant clusters }\end{array}$ & Mouse & [186] \\
\hline $\begin{array}{l}\text { Antiresistance } \\
\text { vaccines }\end{array}$ & $\begin{array}{l}\text { Neisseria } \\
\text { meningitidis }\end{array}$ & $\begin{array}{l}\text { Vaccination with } \\
\text { purified recombinant } \\
\text { PBP2 + passive } \\
\text { immunization with } \\
\text { anti-PBP2 rabbit IgG } \\
\text { antibody }\end{array}$ & $\begin{array}{l}\text { (a) This vaccine candidate } \\
\text { has a conserved region } \\
\text { that is present in all strains } \\
\text { of } N \text {. meningitidis and } \\
\text { targeted by protective } \\
\text { antibodies }\end{array}$ & Mouse & {$[175,188]$} \\
\hline
\end{tabular}




\section{Combination Drug Therapy}

Combination therapy is when a set of drugs are used to treat infections rather than a single drug (monotherapy). Infections caused by causative agents (M. tuberculosis, human immunodeficiency virus, Plasmodium parasite), which are predisposed to develop resistance, are being treated with this method [147]. The use of combination drug therapy acts in multiple dimensions. Recently, for the treatment of gonorrhea, which recommends ceftriaxone or cefixime plus azithromycin [191].

\subsection{Combination Drug Combination Acting on Diverse Targets in Different Pathways}

A classic example is a treatment modality used against $M$. tuberculosis infections currently prevalent in many developing nations like India. Four first-line drugs are used in this regimen: rifampicin $(\mathrm{R})$, isoniazid $(\mathrm{H})$, ethambutol $(\mathrm{E})$, and pyrazinamide $(\mathrm{Z})$; their targets are rifampicin (RNA polymerase inhibitor), isoniazid (enoyl reductase subunit of fatty acid synthase), ethambutol (an inhibitor of arabinosyl transferases involved in cell wall biosynthesis) and pyrazinamide (mechanism of action poorly understood) $[147,192,193]$. This method is highly effective since a bacterium may develop resistance by changing one of its targets; the combination drug strategy will still be effective against at least the other two pathways minimizing the chances of bacterial propagation.

\subsection{Drug Combinations Acting on Diverse Targets in the Same Pathways}

$\beta$-lactamase enzyme produced by Gram-positive bacteria opens up the $\beta$-lactam ring making it non-functional. Thus, this approach involves the use of a $\beta$-lactam antibiotic (amoxicillin) and $\beta$-lactamase enzyme inhibitor (clavulanic acid) $[147,187]$. Clavulanic acid degrades the enzyme, allowing the drug to destroy these microorganisms.

\subsection{Drug Combination Acting on a Single Target, but in Multiple Dimensions}

Streptogramins are made up of two active molecules that bind to the adjacent sites in the 50 S ribosomal subunit near the peptidyl transferase center [194,195]. When both of these molecules are used simultaneously, they show 10-100-fold more potency as compared to using a single molecule alone [196]. Table 6 defines different combinations of drug therapy.

Table 6. Combination drug therapy to defeat the superbugs.

\begin{tabular}{|c|c|c|c|c|}
\hline \multicolumn{5}{|c|}{ Combination Drug Therapy } \\
\hline Agent & $\begin{array}{c}\text { Target Bacteria/ } \\
\text { Diseases }\end{array}$ & Mode of Action/Description & $\begin{array}{c}\text { Notes (Advantages (a), } \\
\text { Limitations (1), Combination } \\
\text { Strategy (c)) }\end{array}$ & Ref \\
\hline \multicolumn{5}{|c|}{ Combination drug combination acting on diverse targets in different pathways } \\
\hline $\begin{array}{l}\text { Rifampicin }(\mathrm{R}), \\
\text { isoniazid }(\mathrm{H}), \\
\text { ethambutol }(\mathrm{E}), \text { and } \\
\text { pyrazinamide }(\mathrm{Z})\end{array}$ & M. tuberculosis & $\begin{array}{l}\text { Rifampicin (RNA polymerase } \\
\text { inhibitor), isoniazid (enoyl } \\
\text { reductase subunit of fatty acid } \\
\text { synthase), ethambutol (an } \\
\text { inhibitor of arabinosyl } \\
\text { transferases involved in cell } \\
\text { wall biosynthesis) and } \\
\text { pyrazinamide (mechanism of } \\
\text { action poorly understood) }\end{array}$ & $\begin{array}{l}\text { (a) Method highly effective since a } \\
\text { bacterium may develop resistance } \\
\text { by changing one of its targets, the } \\
\text { combination drug strategy will } \\
\text { still be effective against at least the } \\
\text { other two pathways }\end{array}$ & {$[147,192,193]$} \\
\hline \multicolumn{5}{|c|}{ Drug combinations acting on diverse targets in the same pathways } \\
\hline Clavulanic acid & $\begin{array}{l}\text { Gram-positive } \\
\text { bacteria }\end{array}$ & $\begin{array}{l}\text { Degrades the } \beta \text {-lactamase } \\
\text { enzyme, allowing the drug to } \\
\text { destroy these microorganisms }\end{array}$ & $\begin{array}{l}\text { (c) Use of a } \beta \text {-lactam antibiotic } \\
\text { (amoxicillin) and } \beta \text {-lactamase } \\
\text { enzyme inhibitor (clavulanic acid) }\end{array}$ & [187] \\
\hline \multicolumn{5}{|c|}{ Drug combination acting on a single target, but in multiple dimensions } \\
\hline Streptogramins & & $\begin{array}{l}\text { Two active molecules that bind } \\
\text { to the adjacent sites in the } 50 S \\
\text { ribosomal subunit near the } \\
\text { peptidyl transferase center }\end{array}$ & $\begin{array}{l}\text { (c) Both of these molecules are } \\
\text { used simultaneously; they show } \\
\text { 10-100-fold more potency as } \\
\text { compared to using a single } \\
\text { molecule alone }\end{array}$ & [194-196] \\
\hline
\end{tabular}




\section{Novel Antibodies against MDR Bacteria}

The conception of monoclonal antibody therapy against MDR superbugs stems from the fruitful usage of serum therapy against bacterial infections. The effectiveness of this technique was authenticated in the clinical trials and is in medical practice since the early 1900s entailing a particular antiserum serving as antimicrobial agents. Serum therapy was aborted with the advent of antibiotics, in some measure, owing to frequent toxicities and the failure to refine or generate antibodies for single determinants back then. Conversely, in the present day, technological and research progress in antibody engineering makes it conceivable to produce distinct, consistent, and completely human (humanized) mAbs with a particular antigen specificity.

A1102 is a humanized mouse gal-III $\mathrm{mAb}$ whose biologic activity in vitro and in vivo was demonstrated in experimental models of K. pneumoniae ST258 infections. It was revealed that upon passive immunization with A1102 before infection with ST258 whole bacteria or ST258-derived LPS increased the survival rate of endotoxin-sensitized mice and also protected rabbits from a lethal infection with ST258. It was shown by in vitro studies that the biological action of A1102 comprising complement and Fc independent LPS neutralization necessitated divalent binding and augmentation of human serum bactericidal eradication and complement-dependent macrophage uptake of ST258 [197].

It had been demonstrated that O25b-specific MAb ASN-4 retained its bactericidal activity against an MCR-1-positive colistin-resistant ST131-H30 strain by three mechanisms of action that are opsonophagocytosis, endotoxin neutralization, and complement-mediated killing. Subsequently, LPS O-antigen-targeting antibodies are thought to be an alternative way of combating MDR infections, including the emerging MCR-1-positive isolates [198]. The general mode of action of novel antibodies against bacteria is depicted in Figure 8.

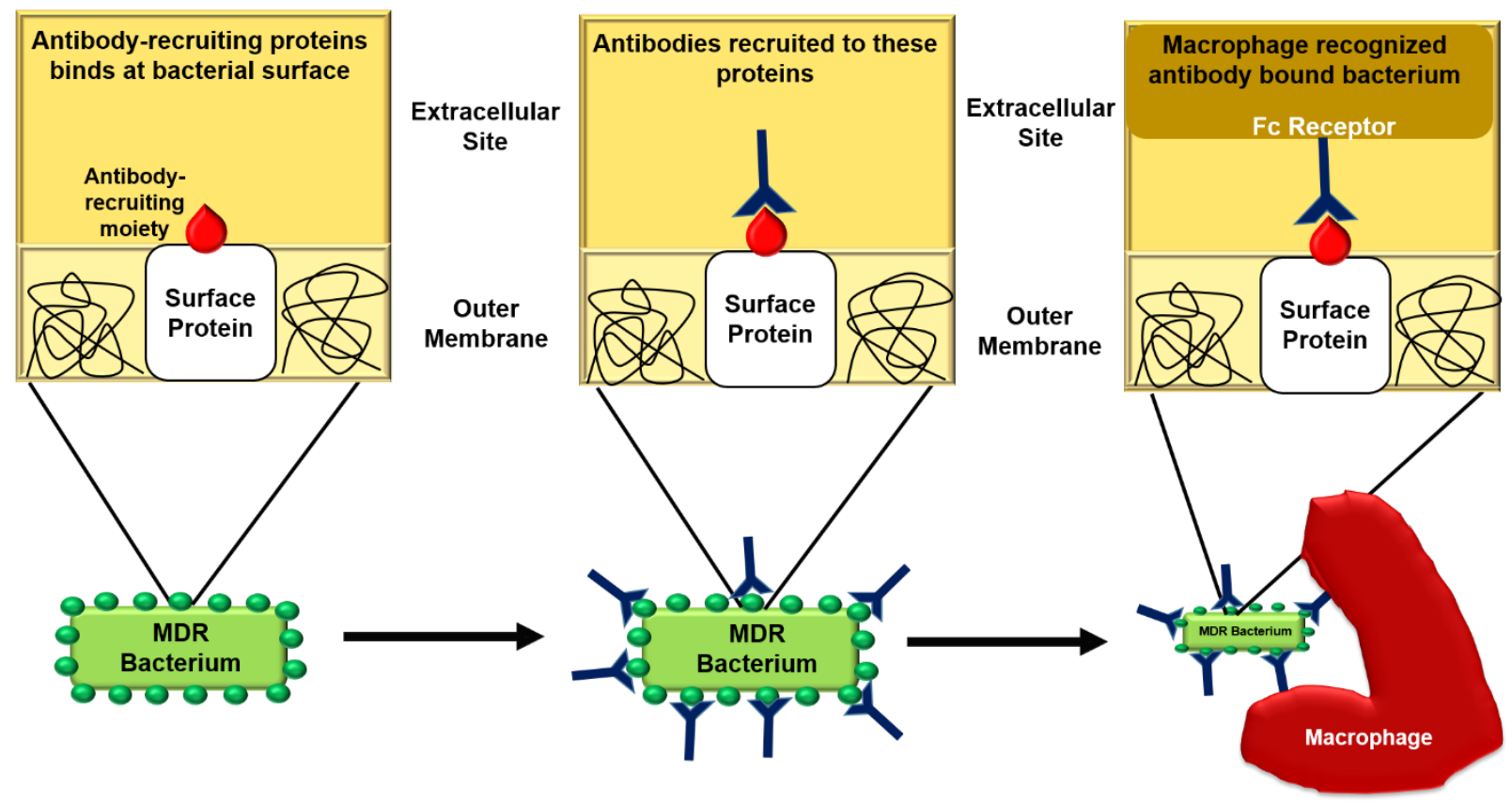

Figure 8. Mode of action of novel antibodies how they bind to multidrug-resistant (MDR) bacteria and present to macrophages and destroy them.

Even though antibody-based approaches of prophylaxis may have substantial potential for the inhibition of bacterial infections, their conspicuous operating principle may correspondingly counterpart antibiotics. Combination drug therapy is broadly considered to diminish the occurrence of resistance, but antibacterial antibodies have likewise been established to deliver assistance when used alongside antibiotics comparative to management with antibiotics single-handedly. For instance, mice doctored with a comparable human dosage of 
tobramycin did not endure infection with a tobramycin-resistant $P$. aeruginosa experimental isolate; however, therapy with tobramycin and a sub-protective MEDI3902 (bispecific antibody targeting the P. aeruginosa type III secretion (T3S) protein PcrV and Psl exopolysaccharide) dosage ensured in mice survival and improved bacterial clearance. Comparable advantages have been described employing using mAbs adjunctively with antibiotics against bacterial infections [199]. Table 7 defines different antibodies against bacteria.

Table 7. Novel antibodies are used against bacteria with and/or without drug combination.

\begin{tabular}{|c|c|c|c|c|c|}
\hline Agent & $\begin{array}{l}\text { Target Bacte- } \\
\text { ria/Diseases }\end{array}$ & $\begin{array}{c}\text { Mode of } \\
\text { Action/Description }\end{array}$ & $\begin{array}{l}\text { Notes (Advantages (a), } \\
\text { Limitations (l), } \\
\text { Combination Strategy } \\
\text { (c)) }\end{array}$ & $\begin{array}{c}\text { In Vitro, In Vivo, } \\
\text { Clinical Phase, Animal } \\
\text { Model }\end{array}$ & Ref \\
\hline \multicolumn{6}{|c|}{ Antibodies } \\
\hline $\begin{array}{c}\text { A1102 } \\
\text { (humanized } \\
\text { mouse gal-III } \\
\text { mAb) }\end{array}$ & $\begin{array}{l}\text { K. pneumoniae } \\
\text { ST258 }\end{array}$ & $\begin{array}{l}\text { Passive immunization } \\
\text { with A1102 before } \\
\text { infection with ST258 } \rightarrow \\
\text { infection prophylaxis }\end{array}$ & $\begin{array}{l}\text { (1) Efficacy and exact } \\
\text { role for protection } \\
\text { in vivo not understood }\end{array}$ & $\begin{array}{l}\text { In vitro and in vivo in } \\
\text { experimental models } \\
\text { (mice) }\end{array}$ & [197] \\
\hline $\begin{array}{l}\text { O25b-specific } \\
\text { mAb ASN-4 }\end{array}$ & $\begin{array}{l}\text { MCR-1-positive } \\
\text { colistin-resistant } \\
\text { ST131-H30 strain }\end{array}$ & $\begin{array}{l}\text { Oopsonophagocytosis, } \\
\text { endotoxin neutralization, } \\
\text { and } \\
\text { complement-mediated } \\
\text { killing }\end{array}$ & $\begin{array}{l}\text { (a) Multiple mechanisms } \\
\text { of action }\end{array}$ & $\begin{array}{l}\text { In vitro and in vivo in } \\
\text { experimental models } \\
\text { (Murine models) }\end{array}$ & [198] \\
\hline MEDI3902 & P. aeruginosa & $\begin{array}{l}\text { Bispecific antibody } \\
\text { targeting the } P \text {. aeruginosa } \\
\text { type III secretion (T3S) } \\
\text { protein PcrV and Psl } \\
\text { exopolysaccharide }\end{array}$ & $\begin{array}{c}\text { (c) In combination with } \\
\text { drug therapy } \\
\text { (antibiotics) deliver } \\
\text { assistance when used } \\
\text { alongside antibiotics }\end{array}$ & In vivo (mice) & [199] \\
\hline
\end{tabular}

\section{Carbon Monoxide-Releasing Molecules (CORMs)}

Studies have been conducted on animal models regarding the usage of hem oxygenase activity intracellular product called carbon monoxide (CO), and its administration as a therapeutic agent showed beneficial effects in treating animal models suffering from inflammatory disorders and cardiovascular diseases as well as in the organ transplantation [200].

However, the same administration of $\mathrm{CO}$ in humans can be hazardous as the levels of systemic carboxyhemoglobin can be raised high enough to cause death. Prodrugs such as carbon monoxide-releasing molecules (CORMs) transfer CO into biological systems. They are considered a safer alternative since they do not affect the transport of oxygen by hemoglobin.

Among all the CORMs reported up to now, metal carbonyl complexes are the most suitable and popular class of compounds. Some other CORMs include oxalates, tertiary aldehydes, silacarboxylates, and boron carboxylates [201]. When the carbonyl groups are attached to the transition metals such as molybdenum, iron or ruthenium, the CORMs exhibit a unique ability to transfer $\mathrm{CO}$ in the cells and enhance the signal transduction mechanisms mediated by CO. Thus, CORMs, as donors of CO, presented an extensive range of biological activities. Moreover, some specific transition metal carbonyls have repeatedly presented cytoprotective properties as well as some curative activities in a wide range of cellular and in vivo models of diseased animals [202,203].

\section{Probiotics}

Probiotics are known to be live microorganisms, primarily belonging to the genus Lactobacillus and Bifidobacterium, which are well-known to have a very advantageous influence on the host organism they inhabit. Concerning antibiotics and MDR, probiotics are seen to participate in diminishing the threat of various infectious diseases, including gastroenteritis and respiratory tract infections. Simultaneous utilization of probiotics with antibiotics has been proven to lessen the occurrence, time period, and/or ruthlessness of antibiotic-linked 
gastroenteritis. This, in turn, has better effects on the adherence properties of the antibiotic, thereby enhancing the efficacy of these antibiotics. Lactobacillus strains are also known to be successful in the defense of the host against urinary tract infections. L. rhamnosus GR1 has an amazing capability to bind with epithelial cells, particularly in the vaginal tract and is not susceptible to spermicidal agents; therefore, the bacterium can avert binding and development of urinary microorganisms [204]. P. aeruginosa has intrinsic resistance to the majority of accessible antibiotics, including aminoglycosides, anti-pseudomonal penicillins, newer cephalosporins, and imipenem. The favorable effect of probiotics may be linked to their aptitude to inhibit the development of drug-resistant bacteria seemingly by the secretion of antibacterial chemicals including lactic acid, hydrogen peroxide, and more diminishing their ability to colonize the body, thereby reducing the use of antibiotics and therefore, the development of MDR as a whole [20,21].

In one current study, indigenous probiotic Lactobacilli and standard Lactobacillus strains were evaluated for their inhibitory activity against MDR K. pneumoniae. Probiotic lactobacilli strains; L. plantarum LMEM7, L. rhamnosus LMEM9, L. acidophilus LMEM8, and L. animalis LMEM6 isolated from curd samples and L. fermentum MTCC 9748 standard strains were used against K. pneumoniae. Results obtained showed that indigenous Lactobacilli could be used against MDR K. pneumoniae in place of antibiotic therapy, and more probiotic strains should be identified against different pathogens [205]. In a similar study, the antimicrobial effect of Propionibacterium freudenreichii derived from dairy had been identified against multidrug-resistant Salmonella heidelberg (SH) in turkey poults. Two strains were used; namely, P. freudenreichii freudenreichii B3523 (PF) and P. freudenreichii shermanii B4327 (PS). The analysis revealed that $P$. freudenreichii could be used as an alternative to antibiotics for preventing SH infections in poults [206]. Table 8 indicates probiotics use to combat bacteria.

Table 8. Different types of probiotics used to combat bacteria.

\begin{tabular}{|c|c|c|c|c|c|}
\hline Agent & $\begin{array}{c}\text { Target } \\
\text { Bacteria/Diseases }\end{array}$ & Mode of Action/Description & $\begin{array}{l}\text { Notes (Advantages (a), } \\
\text { Limitations (l), } \\
\text { Combination Strategy } \\
\text { (c)) }\end{array}$ & Status & Ref. \\
\hline \multicolumn{6}{|c|}{ Probiotics } \\
\hline $\begin{array}{l}\text { Lactobacillus and } \\
\text { Bifidobacterium }\end{array}$ & $\begin{array}{l}\text { E. coli, Salmonella, } \\
\text { Helicobacter pylori, } \\
\text { Listeria } \\
\text { monocytogenes and } \\
\text { rotavirus }\end{array}$ & $\begin{array}{l}\text { Lessen occurrence, time period, } \\
\text { and/or ruthlessness of } \\
\text { antibiotic-linked gastroenteritis } \\
\rightarrow \text { enhancing efficacy of these } \\
\text { antibiotics }\end{array}$ & $\begin{array}{l}\text { (c) Simultaneous } \\
\text { utilization of probiotics } \\
\text { with antibiotics }\end{array}$ & In vivo & [204] \\
\hline $\begin{array}{l}\text { Lactobacillus } \\
\text { acidophilus strain }\end{array}$ & P. aeruginosa & $\begin{array}{c}\text { Inhibit development of } \\
\text { drug-resistant bacteria by } \\
\text { secretion of antibacterial } \\
\text { chemicals including lactic acid, } \\
\text { hydrogen peroxide, } \\
\text { diminishing MDRs ability to } \\
\text { colonize the body } \rightarrow \text { reducing use } \\
\text { of antibiotics }\end{array}$ & $\begin{array}{l}\text { (a) Reduced use of } \\
\text { antibiotics and } \\
\text { development of MDR by } \\
\text { providing protection } \\
\text { against intrinsic resistance } \\
\text { strains }\end{array}$ & In vitro & {$[20,21]$} \\
\hline Lactobacilli & $\begin{array}{c}\text { MDR K. } \\
\text { pneumoniae }\end{array}$ & Used in place of antibiotic therapy & $\begin{array}{c}\text { (1) Require identification } \\
\text { of more strains }\end{array}$ & In vitro & [205] \\
\hline $\begin{array}{c}\text { Propionibacterium } \\
\text { freudenreichii } \\
\text { freudenreichii B3523 } \\
\text { (PF) and P. } \\
\text { freudenreichii } \\
\text { shermanii B4327 } \\
\text { (PS)) }\end{array}$ & $\begin{array}{l}\text { MDR Salmonella } \\
\text { heidelberg }(\mathrm{SH})\end{array}$ & $\begin{array}{l}\text { Used as an alternative to } \\
\text { antibiotics for preventing } \mathrm{SH} \\
\text { infections }\end{array}$ & $\begin{array}{l}\text { (a) Non-host } \\
\text { gastrointestinal } \\
\text { tract-derived probiotic }\end{array}$ & $\begin{array}{l}\text { Turkey } \\
\text { poults }\end{array}$ & [206] \\
\hline
\end{tabular}




\section{Quorum Sensing}

Bacteria interact with each other through small chemical molecules (in a coordinated manner) known as quorum sensing. The buildup of quorum-sensing signals (QSS) in the growth medium reflects cell density, and as soon as a viable concentration is achieved, the QSS trigger transcription factors that in turn upregulate the signal synthase and several other genes. It is accepted that QSS govern virulence factor manifestation, which is our main interest coupled with bioluminescence, making biofilm, admission into stationary phase, sexual conjugation, sporulation, and transformation capability [22].

A huge number of hospital-acquired ailments are associated with infections instigated by biofilm molded on implanted devices. The consequence of these infections can be lengthier hospitalization, surgical operations, and even demise. A peptide molecule is known to hinder biofilm formation and ailments caused by S. aureus, which somehow blocks the quorum sensing (coordination) between bacteria. The heptapeptide, which was initially isolated from post exponential supernatants of $S$. xylosus, is now made in its amide form as a synthetic 7-aa molecule (YSPWTNF-NH2) termed "RNAIII-inhibiting peptide" (RIP). RIP inhibits cell adhesion and biofilm formation; the activity of the gene locus agr, thus preventing the production of a regulatory RNA molecule, RNAIII, that controls the production of toxins and affects the pathogenesis of S. aureus $[135,136]$. The mechanism through which RIP inhibits quorum-sensing mechanisms includes inhibition of the phosphorylation of a protein called "target of RNAIII activating protein". The antibiotic concentration essential to destroy bacteria in the biofilm is 100-1000 times greater than that required to kill the same species outside a biofilm. The greater the use of antibiotics, the more the chances of resistance development against them. Thereby, by reducing the use of antibiotics achieved via quorum sensing inhibition, we can effectively prevent MDR in bacteria [135,207]. Figure 9 represents the mode of action how a quorum quencher can interfere with bacterial communication leading to biofilm inhibition.

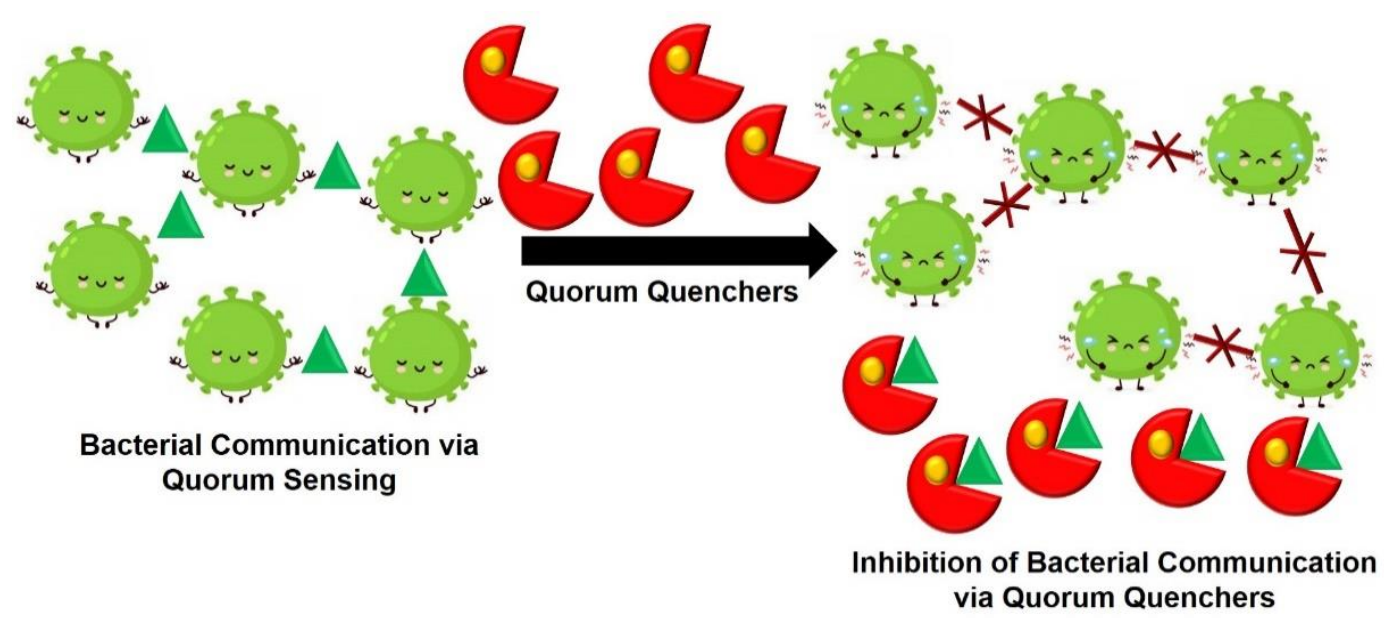

Figure 9. Quorum sensing can be blocked by producing and apply chemical analogs, which render the bacteria unable to communicate and hence pathogenicity-related expression is affected.

\section{Vaccines vs. Drugs: Who Is Going to Win?}

Vaccines are majorly used as prophylactics as opposed to drugs. Vaccines confer immunity to individuals from the pathogens at hand, thereby preventing it from reaching massive numbers in the body, which in turn diminishes the buildup of genetic diversity or recombination frequency as well as culminates any chances for further communication to other hosts. For instance, a tuberculosis vaccine has been reported to reduce a bacterial population peak size up to five times the actual number attained in rodent subjects $[24,208]$. Furthermore, vaccines are designed as such to encompass more than one pathogenic antigen as well as multiple epitopes for the immune system to recognize and develop 
memory against [24,209]. Epitopes are recognized and processed by apparatuses of the immune system comparable to the method of biochemical molecules interacting with a drug. This shows that the immune response is actually like combinational drug therapy. With significant additional component effectors, however, it is revealed that roughly 100 distinctive tetanus-toxoid-specific antibodies can be witnessed in hale and hearty humans after getting a tetanus-toxoid booster vaccine, with distinct antibodies from one individual to another [24,209-211].

\section{How Important Is the Accurate and Rapid Detection of the MDR Bacteria?}

As already discussed in detail that antimicrobial resistance is a worldwide issue that leads to morbidity and mortality. This situation can be resolved by developing rapid diagnostics tools for quick profiling of pathogens, and their resistance [212]; one-way to fight this issue is by prescribing accurate antibiotics. This can be done by proper and rapid differentiation of bacterial and viral infections, and it is difficult to achieve because pathogen isolation, identification, and antibiotic resistance detection take time. This can be resolved by implementing point-of-care (POC) diagnostics. There are three classes of POC diagnostics; one that differentiates between bacterial and viral infections; second, in which detection and report of a specific pathogen are performed, and the third one is, it should not only detect and report a specific pathogen but also exhibit the presence of antibiotic resistance [213].

Many bacterial detection techniques, like infrared light-based devices, polymerase chain reaction (PCR), enzyme-linked immunosorbent assay (ELISA), and chemical assays, are available but are slow and require sophisticated equipment. Culturing is considered the gold standard for the detection of bacteria, but it requires several days to retrieve the final results. Hence, there is a need for those techniques that are not only fast but also sensitive in detecting bacteria. In a new method called whispering gallery mode (WGM), optical microcavity-based sensors were used to detect the bacteria Helicobacter hepaticus. It was shown that this bacterium could easily be detected using WGM optical microcavity-based sensors [214]. WGM sensors can react to environmental perturbations. Their sensitivity, together with the diversity of structures, leads to the development of these devices for a wide range of analytes. These are being used for detecting clinically relevant biomolecules as well as single-protein interactions [215]. Thus, this technique is proven to be faster and potentially sensitive.

Optical (bio)sensors facilitate us by monitoring polarization, intensity, phase, speed, and frequency of light. Whispering gallery mode (WGM) microresonators are at the forefront for over the last two decades [216]. They provide a label-free optical method to detect bacteria rapidly with high sensitivity [217]. They are increasingly used as transducers for detecting specific biomolecules. They can detect biomolecules in a label-free manner without any chemical modifications of the analyte. Additionally, the biophysical properties of biomolecules do not get altered due to probing light. WGM sensors detect biomolecules by recognizing the target analyte through molecular receptors. Thus, WGM frequency shifts that are specific to the analyte molecule are produced. Biomolecular detection is achieved by analyzing the binding of analyte molecules to the receptors and converting the binding event into optical and electrical signals, which are then detected and measured as spectra over time. Receptor molecules that are being used in WGM biosensing are oligonucleotides, antibodies, and proteins [218]. Due to the small mode size of the microcavity, the light which enters the microcavity can cycle multiples of times under TIR (total internal reflection) action. In the meantime, this light extends in the surrounding medium in the form of evanescent waves, and the intensity of the evanescent wave falloffs exponentially. Mode change occurs as a result of any interference in the evanescent field, and this results in substantial variations in the resonant characteristics like mode separation, frequency shifting, and linewidth broadening. This causes the enhancement of interaction between light and matter, which results in realizing unprecedented sensitivity detection [219]. 


\section{Conclusions}

Bacteria are naturally programmed to survive, and it is why they had always been one step ahead of humans. Nevertheless, it is high time to gain the advantage over these menacing creatures by the advent of modern science. To gain an edge over these MDR microorganisms, we must consume our time and energy towards rapid diagnostic systems to equip us with the knowledge of what we are dealing with. Moreover, it is proved through literature that approaches that have nonprotein targets in bacteria are the most promising ones as the bacteria have so far not been able to cope up with it efficiently. To end this continuous war, we must also keep on isolating new drugs with novel modes of action.

Author Contributions: A.A.K. performed the literature search with K.N.M., M.S. and A.T. The manuscript was written by together by A.A.K., K.N.M., A.S., M.S., M.R., S.N. and H.-P.D. The tables were prepared by S.N., S.R. and A.T. The images were made by K.N.M., M.R., M.S. and A.T. The complete writing, design and corrections of the manuscript was led and supervised by A.A.K. and H.-P.D. All authors have read and agreed to the published version of the manuscript.

Funding: We are grateful for support within the project "InfektResonator" (IGF 20,934 N) awarded by the Bundesministerium für Wirtschaft und Energie (BMWi), and for support by the Bundesministerium für Bildung und Forschung, BMBF, (FlowArray project 13FH121PX8), Germany.

Institutional Review Board Statement: Not Applicable.

Informed Consent Statement: Not Applicable.

Data Availability Statement: Not Applicable.

Conflicts of Interest: The authors declare that there is no conflict of interest.

\section{References}

1. Singh, R.; Smitha, M.; Singh, S.P. The role of nanotechnology in combating multi-drug resistant bacteria. J. Nanosci. Nanotechnol. 2014, 14, 4745-4756. [CrossRef]

2. Alekshun, M.N.; Levy, S.B. Molecular mechanisms of antibacterial multidrug resistance. Cell 2007, 128, 1037-1050. [CrossRef]

3. Kaur, I. Novel strategies to combat antimicrobial resistance. J. Infect. Dis. Ther. 2016, 4, 292. [CrossRef]

4. Alanis, A.J. Resistance to antibiotics: Are we in the post-antibiotic era? Arch. Med. Res. 2005, 36, 697-705. [CrossRef] [PubMed]

5. Munita, J.M.; Arias, C.A. Mechanisms of antibiotic resistance. Virulence Mech. Bact. Pathog. 2016, 481-511. [CrossRef]

6. Azucena, E.; Mobashery, S. Aminoglycoside-modifying enzymes: Mechanisms of catalytic processes and inhibition. Drug Resist. Updates 2001, 4, 106-117. [CrossRef] [PubMed]

7. Gill, E.E.; Franco, O.L.; Hancock, R.E. Antibiotic adjuvants: Diverse strategies for controlling drug-resistant pathogens. Chem. Biol. Drug Des. 2015, 85, 56-78. [CrossRef]

8. Bhattacharjya, S.; Ramamoorthy, A. Multifunctional host defense peptides: Functional and mechanistic insights from NMR structures of potent antimicrobial peptides. FEBS J. 2009, 276, 6465-6473. [CrossRef]

9. Bhunia, A.; Domadia, P.N.; Torres, J.; Hallock, K.J.; Ramamoorthy, A.; Bhattacharjya, S. NMR structure of pardaxin, a pore-forming antimicrobial peptide, in lipopolysaccharide micelles mechanism of outer membrane permeabilization. J. Biol. Chem. 2010, 285, 3883-3895. [CrossRef]

10. Blanco, P.; Hernando-Amado, S.; Reales-Calderon, J.A.; Corona, F.; Lira, F.; Alcalde-Rico, M.; Bernardini, A.; Sanchez, M.B.; Martinez, J.L. Bacterial multidrug efflux pumps: Much more than antibiotic resistance determinants. Microorganisms 2016, 4, 14. [CrossRef]

11. Džidić, S.; Šušković, J.; Kos, B. Antibiotic resistance mechanisms in bacteria: Biochemical and genetic aspects. Food Technol. Biotechnol. 2008, 46, 11-21.

12. Khan, S.; Akhtar, M.U.; Khan, S.; Javed, F.; Khan, A.A. Nanoniosome-encapsulated levoflaxicin as an antibacterial agent against Brucella. J. Basic Microbiol. 2020, 60, 281-290. [CrossRef] [PubMed]

13. Talib, A.; Manzoor, K.; Ijaz, A.; Adnan, F.; Javed, F.; Khan, A. Encapsulated virgin coconut oil as a nanoscale in vitro solution against multiple drug resistant Staphylococcus aureus. Micro Nano Lett. 2020. [CrossRef]

14. Talib, A.; Manzoor, K.N.; Ali, W.; Saeed, M.; Gondal, M.A.; Badshah, M.; Khan, A.A. Biogenic Copper Nanoparticles as a Nanoscale Solution to Address Multiple Drug Resistance in Bacteria. Pak. J. Zool. 2021, 53, 201-208. [CrossRef]

15. Rai, M.; Yadav, A.; Gade, A. Silver nanoparticles as a new generation of antimicrobials. Biotechnol. Adv. 2009, 27, 76-83. [CrossRef]

16. Sondi, I.; Salopek-Sondi, B. Silver nanoparticles as antimicrobial agent: A case study on E. coli as a model for Gram-negative bacteria. J. Colloid Interface Sci. 2004, 275, 177-182. [CrossRef]

17. Kim, J.S.; Kuk, E.; Yu, K.N.; Kim, J.-H.; Park, S.J.; Lee, H.J.; Kim, S.H.; Park, Y.K.; Park, Y.H.; Hwang, C.-Y. Antimicrobial effects of silver nanoparticles. Nanomed. Nanotechnol. Biol. Med. 2007, 3, 95-101. [CrossRef] 
18. Zharov, V.P.; Mercer, K.E.; Galitovskaya, E.N.; Smeltzer, M.S. Photothermal nanotherapeutics and nanodiagnostics for selective killing of bacteria targeted with gold nanoparticles. Biophys. J. 2006, 90, 619-627. [CrossRef]

19. Kutateladze, M.; Adamia, R. Bacteriophages as potential new therapeutics to replace or supplement antibiotics. Trends Biotechnol. 2010, 28, 591-595. [CrossRef]

20. Jamalifar, H.; Rahimi, H.; Samadi, N.; Shahverdi, A.; Sharifian, Z.; Hosseini, F.; Eslahi, H.; Fazeli, M. Antimicrobial activity of different Lactobacillus species against multi-drug resistant clinical isolates of Pseudomonas aeruginosa. Iran. J. Microbiol. $2011,3,21$.

21. Gibbs, P. Novel uses for lactic acid fermentation in food preservation. J. Appl. Bacteriol. 1987, 63, 51s-58s. [CrossRef]

22. Rutherford, S.T.; Bassler, B.L. Bacterial quorum sensing: Its role in virulence and possibilities for its control. Cold Spring Harb. Perspect. Med. 2012, 2, a012427. [CrossRef] [PubMed]

23. Joice, R.; Lipsitch, M. Targeting imperfect vaccines against drug-resistance determinants: A strategy for countering the rise of drug resistance. PLoS ONE 2013, 8, e68940. [CrossRef] [PubMed]

24. Kennedy, D.A.; Read, A.F. Why does drug resistance readily evolve but vaccine resistance does not? Proc. R. Soc. B Biol. Sci. 2017, 284, 20162562. [CrossRef] [PubMed]

25. Gupta, A.; Landis, R.F.; Rotello, V.M. Nanoparticle-based antimicrobials: Surface functionality is critical. F1000Research 2016, 5 . F1000 Faculty Rev-364. [CrossRef]

26. Jehan, M.; Saeed, F.; Khan, Z.; Shah, M.; Sikandar, A.; Inayat, A.; Ali, S.; Khan, A.M.; Talib, A.; Aasim, M. Investigative evaluation of Cassia absus for antibacterial capacity and biomimetic synthesis of silver nanoparticles. IET Nanobiotechnol. 2018, 12, 1062-1066. [CrossRef] [PubMed]

27. Kumar, M.; Curtis, A.; Hoskins, C. Application of nanoparticle technologies in the combat against anti-microbial resistance. Pharmaceutics 2018, 10, 11. [CrossRef]

28. Aruguete, D.M.; Kim, B.; Hochella, M.F.; Ma, Y.; Cheng, Y.; Hoegh, A.; Liu, J.; Pruden, A. Antimicrobial nanotechnology: Its potential for the effective management of microbial drug resistance and implications for research needs in microbial nanotoxicology. Environ. Sci. Process. Impacts 2013, 15, 93-102. [CrossRef]

29. Kim, C.-B.; Yi, D.K.; Kim, P.S.S.; Lee, W.; Kim, M.J. Rapid photothermal lysis of the pathogenic bacteria, Escherichia coli using synthesis of gold nanorods. J. Nanosci. Nanotechnol. 2009, 9, 2841-2845. [CrossRef]

30. Shrivastava, S.; Bera, T.; Roy, A.; Singh, G.; Ramachandrarao, P.; Dash, D. Characterization of enhanced antibacterial effects of novel silver nanoparticles. Nanotechnology 2007, 18, 225103. [CrossRef]

31. Feng, Q.L.; Wu, J.; Chen, G.Q.; Cui, F.; Kim, T.; Kim, J. A mechanistic study of the antibacterial effect of silver ions on Escherichia coli and Staphylococcus aureus. J. Biomed. Mater. Res. 2000, 52, 662-668. [CrossRef]

32. Cui, Y.; Zhao, Y.; Tian, Y.; Zhang, W.; Lü, X.; Jiang, X. The molecular mechanism of action of bactericidal gold nanoparticles on Escherichia coli. Biomaterials 2012, 33, 2327-2333. [CrossRef] [PubMed]

33. Rudramurthy, G.R.; Swamy, M.K.; Sinniah, U.R.; Ghasemzadeh, A. Nanoparticles: Alternatives against drug-resistant pathogenic microbes. Molecules 2016, 21, 836. [CrossRef] [PubMed]

34. Hayden, S.C.; Zhao, G.; Saha, K.; Phillips, R.L.; Li, X.; Miranda, O.R.; Rotello, V.M.; El-Sayed, M.A.; Schmidt-Krey, I.; Bunz, U.H. Aggregation and interaction of cationic nanoparticles on bacterial surfaces. J. Am. Chem. Soc. 2012, 134, 6920-6923. [CrossRef] [PubMed]

35. Li, X.; Robinson, S.M.; Gupta, A.; Saha, K.; Jiang, Z.; Moyano, D.F.; Sahar, A.; Riley, M.A.; Rotello, V.M. Functional gold nanoparticles as potent antimicrobial agents against multi-drug-resistant bacteria. ACS Nano 2014, 8, 10682-10686. [CrossRef]

36. Zhao, Y.; Tian, Y.; Cui, Y.; Liu, W.; Ma, W.; Jiang, X. Small molecule-capped gold nanoparticles as potent antibacterial agents that target gram-negative bacteria. J. Am. Chem. Soc. 2010, 132, 12349-12356. [CrossRef]

37. Obuya, E.A.; Joshi, P.C.; Gray, T.A.; Keane, T.C.; Jones, W.E., Jr. Application of Pt. $\mathrm{TiO}_{2}$ nanofibers in photosensitized degradation of Rhodamine B. Int. J. Chem. 2014, 6, 1-16.

38. Raghunath, A.; Perumal, E. Metal oxide nanoparticles as antimicrobial agents: A promise for the future. Int. J. Antimicrob. Agents 2017, 49, 137-152. [CrossRef]

39. Ren, G.; Hu, D.; Cheng, E.W.; Vargas-Reus, M.A.; Reip, P.; Allaker, R.P. Characterisation of copper oxide nanoparticles for antimicrobial applications. Int. J. Antimicrob. Agents 2009, 33, 587-590. [CrossRef]

40. Maniprasad, P.; Santra, S. Novel copper $(\mathrm{Cu})$ loaded core-shell silica nanoparticles with improved Cu bioavailability: Synthesis, characterization and study of antibacterial properties. J. Biomed. Nanotechnol. 2012, 8, 558-566. [CrossRef]

41. Huang, Z.; Zheng, X.; Yan, D.; Yin, G.; Liao, X.; Kang, Y.; Yao, Y.; Huang, D.; Hao, B. Toxicological effect of ZnO nanoparticles based on bacteria. Langmuir 2008, 24, 4140-4144. [CrossRef]

42. Król, A.; Pomastowski, P.; Rafińska, K.; Railean-Plugaru, V.; Buszewski, B. Zinc oxide nanoparticles: Synthesis, antiseptic activity and toxicity mechanism. Adv. Colloid Interface Sci. 2017, 249, 37-52. [CrossRef] [PubMed]

43. Ansari, M.A.; Khan, H.M.; Khan, A.A.; Sultan, A.; Azam, A. Synthesis and characterization of the antibacterial potential of ZnO nanoparticles against extended-spectrum $\beta$-lactamases-producing Escherichia coli and Klebsiella pneumoniae isolated from a tertiary care hospital of North India. Appl. Microbiol. Biotechnol. 2012, 94, 467-477. [CrossRef] [PubMed]

44. Salem, W.; Leitner, D.R.; Zingl, F.G.; Schratter, G.; Prassl, R.; Goessler, W.; Reidl, J.; Schild, S. Antibacterial activity of silver and zinc nanoparticles against Vibrio cholerae and enterotoxic Escherichia coli. Int. J. Med Microbiol. 2015, 305, 85-95. [CrossRef] [PubMed] 
45. Xie, Y.; He, Y.; Irwin, P.L.; Jin, T.; Shi, X. Antibacterial activity and mechanism of action of zinc oxide nanoparticles against Campylobacter jejuni. Appl. Environ. Microbiol. 2011, 77, 2325-2331. [CrossRef]

46. Reddy, L.S.; Nisha, M.M.; Joice, M.; Shilpa, P. Antimicrobial activity of zinc oxide (ZnO) nanoparticle against Klebsiella pneumoniae. Pharm. Biol. 2014, 52, 1388-1397. [CrossRef]

47. Jones, M.L.; Ganopolsky, J.G.; Labbé, A.; Wahl, C.; Prakash, S. Antimicrobial properties of nitric oxide and its application in antimicrobial formulations and medical devices. Appl. Microbiol. Biotechnol. 2010, 88, 401-407. [CrossRef]

48. Schairer, D.O.; Chouake, J.S.; Nosanchuk, J.D.; Friedman, A.J. The potential of nitric oxide releasing therapies as antimicrobial agents. Virulence 2012, 3, 271-279. [CrossRef]

49. Rubbo, H.; Radi, R.; Trujillo, M.; Telleri, R.; Kalyanaraman, B.; Barnes, S.; Kirk, M.; Freeman, B.A. Nitric oxide regulation of superoxide and peroxynitrite-dependent lipid peroxidation. Formation of novel nitrogen-containing oxidized lipid derivatives. J. Biol. Chem. 1994, 269, 26066-26075. [CrossRef]

50. Deupree, S.M.; Schoenfisch, M.H. Morphological analysis of the antimicrobial action of nitric oxide on Gram-negative pathogens using atomic force microscopy. Acta Biomater. 2009, 5, 1405-1415. [CrossRef]

51. Drapier, J.; Pellat, C.; Henry, Y. Generation of EPR-detectable nitrosyl-iron complexes in tumor target cells cocultured with activated macrophages. J. Biol. Chem. 1991, 266, 10162-10167. [CrossRef]

52. Ischiropoulos, H.; Al-Mehdi, A.B. Peroxynitrite-mediated oxidative protein modifications. FEBS Lett. 1995, 364, $279-282$. [CrossRef]

53. Laval, F.; Wink, D.; Laval, J. A discussion of mechanisms of NO genotoxicty: Implication of inhibition of DNA repair proteins. In Reviews of Physiology Biochemistry and Pharmacology; Springer: Berlin/Heidelberg, Germany, 1997; Volume 131, pp. 175-191.

54. Laval, F.; Wink, D.A. Inhibition by nitric oxide of the repair protein, O 6-DNA-methyltransferase. Carcinogenesis 1994, 15, 443-447. [CrossRef] [PubMed]

55. Rai, M.K.; Deshmukh, S.; Ingle, A.; Gade, A. Silver nanoparticles: The powerful nanoweapon against multidrug-resistant bacteria. J. Appl. Microbiol. 2012, 112, 841-852. [CrossRef]

56. Friedman, A.; Blecher, K.; Sanchez, D.; Tuckman-Vernon, C.; Gialanella, P.; Friedman, J.M.; Martinez, L.R.; Nosanchuk, J.D. Susceptibility of Gram-positive and-negative bacteria to novel nitric oxide-releasing nanoparticle technology. Virulence 2011, 2, 217-221. [CrossRef] [PubMed]

57. Reighard, K.P.; Schoenfisch, M.H. Antibacterial action of nitric oxide-releasing chitosan oligosaccharides against Pseudomonas aeruginosa under aerobic and anaerobic conditions. Antimicrob. Agents Chemother. 2015, 59, 6506-6513. [CrossRef]

58. Chen, M.-C.; Mi, F.-L.; Liao, Z.-X.; Hsiao, C.-W.; Sonaje, K.; Chung, M.-F.; Hsu, L.-W.; Sung, H.-W. Recent advances in chitosanbased nanoparticles for oral delivery of macromolecules. Adv. Drug Deliv. Rev. 2013, 65, 865-879. [CrossRef]

59. Ghadi, A.; Mahjoub, S.; Tabandeh, F.; Talebnia, F. Synthesis and optimization of chitosan nanoparticles: Potential applications in nanomedicine and biomedical engineering. Casp. J. Intern. Med. 2014, 5, 156.

60. Al-Bakri, A.G.; Mahmoud, N.N. Photothermal-induced antibacterial activity of gold nanorods loaded into polymeric hydrogel against Pseudomonas aeruginosa biofilm. Molecules 2019, 24, 2661. [CrossRef]

61. Mahmoud, N.N.; Alkilany, A.M.; Khalil, E.A.; Al-Bakri, A.G. Nano-photothermal ablation effect of hydrophilic and hydrophobic functionalized gold nanorods on Staphylococcus aureus and Propionibacterium acnes. Sci. Rep. 2018, 8, 6881. [CrossRef]

62. Pattani, V.P.; Tunnell, J.W. Nanoparticle-mediated photothermal therapy: A comparative study of heating for different particle types. Lasers Surg. Med. 2012, 44, 675-684. [CrossRef] [PubMed]

63. Pissuwan, D.; Cortie, C.H.; Valenzuela, S.M.; Cortie, M.B. Functionalised gold nanoparticles for controlling pathogenic bacteria. Trends Biotechnol. 2010, 28, 207-213. [CrossRef] [PubMed]

64. Li, J.-L.; Gu, M. Gold-nanoparticle-enhanced cancer photothermal therapy. IEEE J. Sel. Top. Quantum Electron. 2009, 16, 989-996.

65. Mocan, L.; Tabaran, F.A.; Mocan, T.; Pop, T.; Mosteanu, O.; Agoston-Coldea, L.; Matea, C.T.; Gonciar, D.; Zdrehus, C.; Iancu, C. Laser thermal ablation of multidrug-resistant bacteria using functionalized gold nanoparticles. Int. J. Nanomed. 2017, $12,2255$. [CrossRef] [PubMed]

66. Silvero, C.M.J.N.; Rocca, D.M.; de la Villarmois, E.A.; Fournier, K.; Lanterna, A.E.; Perez, M.F.; Becerra, M.C.; Scaiano, J.C. Selective photoinduced antibacterial activity of amoxicillin-coated gold nanoparticles: From one-step synthesis to in vivo cytocompatibility. ACS Omega 2018, 3, 1220-1230. [CrossRef]

67. Huang, W.-C.; Tsai, P.-J.; Chen, Y.-C. Functional gold nanoparticles as photothermal agents for selective-killing of pathogenic bacteria. Nanomedicine 2007, 2. [CrossRef]

68. Esmaeillou, M.; Zarrini, G.; Rezaee, M.A. Vancomycin capped with silver nanoparticles as an antibacterial agent against multi-drug resistance bacteria. Adv. Pharm. Bull. 2017, 7, 479. [CrossRef]

69. Norman, R.S.; Stone, J.W.; Gole, A.; Murphy, C.J.; Sabo-Attwood, T.L. Targeted photothermal lysis of the pathogenic bacteria, Pseudomonas aeruginosa, with gold nanorods. Nano Lett. 2008, 8, 302-306. [CrossRef]

70. Fan, Z.; Senapati, D.; Khan, S.A.; Singh, A.K.; Hamme, A.; Yust, B.; Sardar, D.; Ray, P.C. Popcorn-Shaped Magnetic Core-Plasmonic Shell Multifunctional Nanoparticles for the Targeted Magnetic Separation and Enrichment, Label-Free SERS Imaging, and Photothermal Destruction of Multidrug-Resistant Bacteria. Chem.-Eur. J. 2013, 19, 2839-2847. [CrossRef]

71. Perni, S.; Piccirillo, C.; Pratten, J.; Prokopovich, P.; Chrzanowski, W.; Parkin, I.P.; Wilson, M. The antimicrobial properties of light-activated polymers containing methylene blue and gold nanoparticles. Biomaterials 2009, 30, 89-93. [CrossRef] 
72. Lima, E.; Guerra, R.; Lara, V.; Guzmán, A. Gold nanoparticles as efficient antimicrobial agents for Escherichia coli and Salmonella typhi. Chem. Cent. J. 2013, 7, 11. [CrossRef] [PubMed]

73. Ivask, A.; ElBadawy, A.; Kaweeteerawat, C.; Boren, D.; Fischer, H.; Ji, Z.; Chang, C.H.; Liu, R.; Tolaymat, T.; Telesca, D. Toxicity mechanisms in Escherichia coli vary for silver nanoparticles and differ from ionic silver. ACS Nano 2014, 8, 374-386. [CrossRef] [PubMed]

74. Matsumura, Y.; Yoshikata, K.; Kunisaki, S.-I.; Tsuchido, T. Mode of bactericidal action of silver zeolite and its comparison with that of silver nitrate. Appl. Environ. Microbiol. 2003, 69, 4278-4281. [CrossRef]

75. Ayala-Núñez, N.V.; Villegas, H.H.L.; Turrent, L.D.C.I.; Padilla, C.R. Silver nanoparticles toxicity and bactericidal effect against methicillin-resistant Staphylococcus aureus: Nanoscale does matter. Nanobiotechnology 2009, 5, 2-9. [CrossRef]

76. Nanda, A.; Saravanan, M. Biosynthesis of silver nanoparticles from Staphylococcus aureus and its antimicrobial activity against MRSA and MRSE. Nanomed. Nanotechnol. Biol. Med. 2009, 5, 452-456. [CrossRef]

77. Lara, H.H.; Ayala-Núñez, N.V.; Turrent, L.D.; Padilla, C.R. Bactericidal effect of silver nanoparticles against multidrug-resistant bacteria. World J. Microbiol. Biotechnol. 2010, 26, 615-621. [CrossRef]

78. Suresh, A.K.; Pelletier, D.A.; Doktycz, M.J. Relating nanomaterial properties and microbial toxicity. Nanoscale 2013, 5, 463-474. [CrossRef]

79. Talib, A.; Khan, A.A.; Ahmed, H.; Jilani, G. The nano-magnetic dancing of bacteria hand-in-hand with oxygen. Braz. Arch. Biol. Technol. 2017, 60. [CrossRef]

80. Talib, A.; Khan, Z.; Bokhari, H.; Hidayathula, S.; Jilani, G.; Khan, A.A. Respiring cellular nano-magnets. Mater. Sci. Eng. C 2017, 80, 526-531. [CrossRef]

81. Vigneshwaran, N.; Kathe, A.A.; Varadarajan, P.; Nachane, R.P.; Balasubramanya, R. Biomimetics of silver nanoparticles by white rot fungus, Phaenerochaete chrysosporium. Colloids Surf. B Biointerfaces 2006, 53, 55-59. [CrossRef]

82. Durán, N.; Marcato, P.D.; Alves, O.L.; De Souza, G.I.; Esposito, E. Mechanistic aspects of biosynthesis of silver nanoparticles by several Fusarium oxysporum strains. J. Nanobiotechnol. 2005, 3, 8.

83. Antony, J.J.; Sivalingam, P.; Siva, D.; Kamalakkannan, S.; Anbarasu, K.; Sukirtha, R.; Krishnan, M.; Achiraman, S. Comparative evaluation of antibacterial activity of silver nanoparticles synthesized using Rhizophora apiculata and glucose. Colloids Surf. B Biointerfaces 2011, 88, 134-140. [CrossRef] [PubMed]

84. Gunalan, S.; Sivaraj, R.; Rajendran, V. Green synthesized ZnO nanoparticles against bacterial and fungal pathogens. Prog. Nat. Sci. Mater. Int. 2012, 22, 693-700. [CrossRef]

85. Martınez-Flores, E.; Negrete, J.; Villasenor, G.T. Structure and properties of Zn-Al-Cu alloy reinforced with alumina particles. Mater. Des. 2003, 24, 281-286. [CrossRef]

86. Ravishankar Rai, V. Nanoparticles and Their Potential Application as Antimicrobials. 2011. Available online: http://citeseerx.ist. psu.edu/viewdoc/summary?doi=10.1.1.459.8922 (accessed on 21 June 2020).

87. Ghorbani, H.R. A review of methods for synthesis of Al nanoparticles. Orient. J. Chem. 2014, 30, 1941-1949. [CrossRef]

88. Sadiq, I.M.; Chowdhury, B.; Chandrasekaran, N.; Mukherjee, A. Antimicrobial sensitivity of Escherichia coli to alumina nanoparticles. Nanomed. Nanotechnol. Biol. Med. 2009, 5, 282-286. [CrossRef]

89. Balasubramanyam, A.; Sailaja, N.; Mahboob, M.; Rahman, M.; Hussain, S.M.; Grover, P. In vitro mutagenicity assessment of aluminium oxide nanomaterials using the Salmonella/microsome assay. Toxicol. In Vitro 2010, 24, 1871-1876. [CrossRef]

90. Manyasree, D.; Kiranmayi, P.; Kumar, R. Synthesis, characterization and antibacterial activity of aluminium oxide nanoparticles. Int. J. Pharm. Pharm. Sci. 2018, 10, 32-35.

91. Chen, C.-W.; Hsu, C.-Y.; Lai, S.-M.; Syu, W.-J.; Wang, T.-Y.; Lai, P.-S. Metal nanobullets for multidrug resistant bacteria and biofilms. Adv. Drug Deliv. Rev. 2014, 78, 88-104. [CrossRef]

92. Adams, L.K.; Lyon, D.Y.; Alvarez, P.J. Comparative eco-toxicity of nanoscale TiO2, $\mathrm{SiO} 2$, and ZnO water suspensions. Water Res. 2006, 40, 3527-3532. [CrossRef]

93. Jiang, W.; Mashayekhi, H.; Xing, B. Bacterial toxicity comparison between nano-and micro-scaled oxide particles. Environ. Pollut. 2009, 157, 1619-1625. [CrossRef] [PubMed]

94. Vale, N.; Correia, A.; Silva, S.; Figueiredo, P.; Mäkilä, E.; Salonen, J.; Hirvonen, J.; Pedrosa, J.; Santos, H.A.; Fraga, A. Preparation and biological evaluation of ethionamide-mesoporous silicon nanoparticles against Mycobacterium tuberculosis. Bioorg. Med. Chem. Lett. 2017, 27, 403-405. [CrossRef] [PubMed]

95. Polkovnikova, Y.A.; Lenshin, A.; Seredin, P.; Minakov, D. Porous silicon nanoparticles containing neurotropic drugs. Inorg. Mater 2017, 53, 477-483. [CrossRef]

96. Choi, S.-R.; Britigan, B.E.; Moran, D.M.; Narayanasamy, P. Gallium nanoparticles facilitate phagosome maturation and inhibit growth of virulent Mycobacterium tuberculosis in macrophages. PLoS ONE 2017, 12, e0177987. [CrossRef] [PubMed]

97. Choi, S.-R.; Britigan, B.E.; Narayanasamy, P. Treatment of virulent Mycobacterium tuberculosis and HIV coinfected macrophages with gallium nanoparticles inhibits pathogen growth and modulates macrophage cytokine production. Msphere 2019, 4, e00443-19. [CrossRef]

98. Li, W.; Cao, Z.; Liu, R.; Liu, L.; Li, H.; Li, X.; Chen, Y.; Lu, C.; Liu, Y. AuNPs as an important inorganic nanoparticle applied in drug carrier systems. Artif. Cells Nanomed. Biotechnol. 2019, 47, 4222-4233. [CrossRef]

99. Zhao, X.; Drlica, K. Reactive oxygen species and the bacterial response to lethal stress. Curr. Opin. Microbiol. 2014, 21, 1-6. [CrossRef] 
100. Nijnik, A.; Hancock, R. Host defence peptides: Antimicrobial and immunomodulatory activity and potential applications for tackling antibiotic-resistant infections. Emerg. Health Threat. J. 2009, 2, 7078. [CrossRef]

101. Vineeth Kumar, T.P.V.K.; Asha, R.; Shyla, G.; George, S. Identification and characterization of novel host defense peptides from the skin secretion of the fungoid frog, Hydrophylax bahuvistara (Anura: Ranidae). Chem. Biol. Drug Des. 2018, 92, 1409-1418. [CrossRef]

102. Ganz, T. Defensins: Antimicrobial peptides of innate immunity. Nat. Rev. Immunol. 2003, 3, 710-720. [CrossRef]

103. Agerberth, B.; Charo, J.; Werr, J.; Olsson, B.; Idali, F.; Lindbom, L.; Kiessling, R.; Jörnvall, H.; Wigzell, H.; Gudmundsson, G.H. The human antimicrobial and chemotactic peptides LL-37 and $\alpha$-defensins are expressed by specific lymphocyte and monocyte populations. Blood J. Am. Soc. Hematol. 2000, 96, 3086-3093.

104. Wehkamp, J.; Schmid, M.; Stange, E.F. Defensins and other antimicrobial peptides in inflammatory bowel disease. Curr. Opin. Gastroenterol. 2007, 23, 370-378. [CrossRef] [PubMed]

105. Wu, J.; Liu, S.; Wang, H. Invasive fungi-derived defensins kill drug-resistant bacterial pathogens. Peptides 2018, 99, 82-91. [CrossRef] [PubMed]

106. Zanetti, M. Cathelicidins, multifunctional peptides of the innate immunity. J. Leukoc. Biol. 2004, 75, 39-48. [CrossRef] [PubMed]

107. Bowdish, D.M.; Davidson, D.J.; Lau, Y.E.; Lee, K.; Scott, M.G.; Hancock, R.E. Impact of LL-37 on anti-infective immunity. J. Leukoc. Biol. 2005, 77, 451-459. [CrossRef]

108. Cai, S.; Qiao, X.; Feng, L.; Shi, N.; Wang, H.; Yang, H.; Guo, Z.; Wang, M.; Chen, Y.; Wang, Y. Python cathelicidin CATHPb1 protects against multidrug-resistant staphylococcal infections by antimicrobial-immunomodulatory duality. J. Med. Chem. 2018, 61, 2075-2086. [CrossRef]

109. Wimley, W.C.; Hristova, K. Antimicrobial peptides: Successes, challenges and unanswered questions. J. Membr. Biol. 2011, 239, 27-34. [CrossRef]

110. Liu, F.; Soh Yan Ni, A.; Lim, Y.; Mohanram, H.; Bhattacharjya, S.; Xing, B. Lipopolysaccharide neutralizing peptide-porphyrin conjugates for effective photoinactivation and intracellular imaging of Gram-negative bacteria strains. Bioconjug. Chem. 2012, 23, 1639-1647. [CrossRef]

111. Jefferson, K.K. What drives bacteria to produce a biofilm? FEMS Microbiol. Lett. 2004, 236, 163-173. [CrossRef]

112. Costerton, J.W.; Stewart, P.S.; Greenberg, E.P. Bacterial biofilms: A common cause of persistent infections. Science 1999, 284, 1318-1322. [CrossRef]

113. Hancock, R.E.; Sahl, H.-G. Antimicrobial and host-defense peptides as new anti-infective therapeutic strategies. Nat. Biotechnol. 2006, 24, 1551-1557. [CrossRef] [PubMed]

114. Rollema, H.S.; Kuipers, O.P.; Both, P.; De Vos, W.M.; Siezen, R.J. Improvement of solubility and stability of the antimicrobial peptide nisin by protein engineering. Appl. Environ. Microbiol. 1995, 61, 2873-2878. [CrossRef] [PubMed]

115. Pepperney, A.; Chikindas, M.L. Antibacterial peptides: Opportunities for the prevention and treatment of dental caries. Probiot. Antimicrob. Proteins 2011, 3, 68. [CrossRef] [PubMed]

116. Yoshida, T.; Nagasawa, T. E-Poly-L-lysine: Microbial production, biodegradation and application potential. Appl. Microbiol. Biotechnol. 2003, 62, 21-26. [CrossRef] [PubMed]

117. Melo, M.N.; Dugourd, D.; Castanho, M.A. Omiganan pentahydrochloride in the front line of clinical applications of antimicrobial peptides. Recent Pat. Anti-Infect. Drug Discov. 2006, 1, 201-207. [CrossRef] [PubMed]

118. Kazemzadeh-Narbat, M.; Kindrachuk, J.; Duan, K.; Jenssen, H.; Hancock, R.E.; Wang, R. Antimicrobial peptides on calcium phosphate-coated titanium for the prevention of implant-associated infections. Biomaterials 2010, 31, 9519-9526. [CrossRef] [PubMed]

119. Aka, S.T. Killing efficacy and anti-biofilm activity of synthetic human cationic antimicrobial peptide cathelicidin hCAP-18/LL37 against urinary tract pathogens. J. Microbiol. Infect. Dis. 2015, 5, 15-20. [CrossRef]

120. Anunthawan, T.; De La Fuente-Núñez, C.; Hancock, R.E.; Klaynongsruang, S. Cationic amphipathic peptides KT2 and RT2 are taken up into bacterial cells and kill planktonic and biofilm bacteria. Biochim. Biophys. Acta (BBA)-Biomembr. 2015, 1848, 1352-1358. [CrossRef]

121. Pletzer, D.; Coleman, S.R.; Hancock, R.E. Anti-biofilm peptides as a new weapon in antimicrobial warfare. Curr. Opin. Microbiol. 2016, 33, 35-40. [CrossRef]

122. Ribeiro, S.M.; De La Fuente-Núñez, C.; Baquir, B.; Faria-Junior, C.; Franco, O.L.; Hancock, R.E. Antibiofilm peptides increase the susceptibility of carbapenemase-producing Klebsiella pneumoniae clinical isolates to $\beta$-lactam antibiotics. Antimicrob. Agents Chemother. 2015, 59, 3906-3912. [CrossRef]

123. Jorge, P.; Lourenco, A.; Pereira, M.O. New trends in peptide-based anti-biofilm strategies: A review of recent achievements and bioinformatic approaches. Biofouling 2012, 28, 1033-1061. [CrossRef] [PubMed]

124. Rapaport, D.; Shai, Y. Interaction of fluorescently labeled pardaxin and its analogues with lipid bilayers. J. Biol. Chem. 1991, 266, 23769-23775. [CrossRef]

125. Ludtke, S.J.; He, K.; Heller, W.T.; Harroun, T.A.; Yang, L.; Huang, H.W. Membrane pores induced by magainin. Biochemistry 1996, 35, 13723-13728. [CrossRef] [PubMed]

126. Wang, Z.; Shen, Y.; Haapasalo, M. Antibiofilm peptides against oral biofilms. J. Oral Microbiol. 2017, 9, 1327308. [CrossRef] [PubMed] 
127. Gazit, E.; Miller, I.R.; Biggin, P.C.; Sansom, M.S.; Shai, Y. Structure and orientation of the mammalian antibacterial peptide cecropin P1 within phospholipid membranes. J. Mol. Biol. 1996, 258, 860-870. [CrossRef]

128. Chung, P.Y.; Khanum, R. Antimicrobial peptides as potential anti-biofilm agents against multidrug-resistant bacteria. J. Microbiol. Immunol. Infect. 2017, 50, 405-410. [CrossRef]

129. das Neves, R.C.; Mortari, M.R.; Schwartz, E.F.; Kipnis, A.; Junqueira-Kipnis, A.P. Antimicrobial and antibiofilm effects of peptides from venom of social Wasp and scorpion on multidrug-resistant Acinetobacter baumannii. Toxins 2019, 11, 216. [CrossRef]

130. Bessa, L.J.; Eaton, P.; Dematei, A.; Plácido, A.; Vale, N.; Gomes, P.; Delerue-Matos, C.; Sa Leite, J.R.; Gameiro, P. Synergistic and antibiofilm properties of ocellatin peptides against multidrug-resistant Pseudomonas aeruginosa. Future Microbiol. 2018, 13, 151-163. [CrossRef]

131. Gunn, J.S.; Bakaletz, L.O.; Wozniak, D.J. What's on the outside matters: The role of the extracellular polymeric substance of gram-negative biofilms in evading host immunity and as a target for therapeutic intervention. J. Biol. Chem. 2016, 291, 12538-12546. [CrossRef]

132. Otto, M. Bacterial sensing of antimicrobial peptides. In Bacterial Sensing and Signaling; Karger Publishers: Basel, Switzerland, 2009; Volume 16, pp. 136-149.

133. Batoni, G.; Maisetta, G.; Lisa Brancatisano, F.; Esin, S.; Campa, M. Use of antimicrobial peptides against microbial biofilms: Advantages and limits. Curr. Med. Chem. 2011, 18, 256-279. [CrossRef]

134. Gooderham, W.J.; Bains, M.; McPhee, J.B.; Wiegand, I.; Hancock, R.E. Induction by cationic antimicrobial peptides and involvement in intrinsic polymyxin and antimicrobial peptide resistance, biofilm formation, and swarming motility of PsrA in Pseudomonas aeruginosa. J. Bacteriol. 2008, 190, 5624-5634. [CrossRef] [PubMed]

135. Chung, P.Y.; Toh, Y.S. Anti-biofilm agents: Recent breakthrough against multi-drug resistant Staphylococcus aureus. Pathog. Dis. 2014, 70, 231-239. [CrossRef] [PubMed]

136. Kong, K.-F.; Vuong, C.; Otto, M. Staphylococcus quorum sensing in biofilm formation and infection. Int. J. Med. Microbiol. 2006, 296, 133-139. [CrossRef]

137. Weinbauer, M.G. Ecology of prokaryotic viruses. FEMS Microbiol. Rev. 2004, 28, 127-181. [CrossRef] [PubMed]

138. Karthik, K.; Muneeswaran, N.S.; Manjunathachar, H.V.; Gopi, M.; Elamurugan, A.; Kalaiyarasu, S. Bacteriophages: Effective alternative to antibiotics. Adv. Anim. Vet. Sci. 2014, 2, 1-7. [CrossRef]

139. Salmond, G.P.; Fineran, P.C. A century of the phage: Past, present and future. Nat. Rev. Microbiol. 2015, 13, 777-786. [CrossRef]

140. Tiwari, R.; Dhama, K.; Kumar, A.; Rahal, A.; Kapoor, S. Bacteriophage therapy for safeguarding animal and human health: A review. Pak. J. Biol. Sci. PJBS 2014, 17, 301-315. [CrossRef]

141. Dhama, K.; Chakraborty, S.; Wani, M.Y.; Verma, A.K.; Deb, R.; Tiwari, R.; Kapoor, S. Novel and emerging therapies safeguarding health of humans and their companion animals: A review. Pak. J. Biol. Sci. PJBS 2013, 16, 101. [CrossRef]

142. Westwater, C.; Kasman, L.M.; Schofield, D.A.; Werner, P.A.; Dolan, J.W.; Schmidt, M.G.; Norris, J.S. Use of genetically engineered phage to deliver antimicrobial agents to bacteria: An alternative therapy for treatment of bacterial infections. Antimicrob. Agents Chemother. 2003, 47, 1301-1307. [CrossRef]

143. Carvalho, C.M.; Gannon, B.W.; Halfhide, D.E.; Santos, S.B.; Hayes, C.M.; Roe, J.M.; Azeredo, J. The in vivo efficacy of two administration routes of a phage cocktail to reduce numbers of Campylobacter coli and Campylobacter jejuni in chickens. BMC Microbiol. 2010, 10, 232. [CrossRef]

144. Tiwari, R.; Dhama, K.; Wani, M.Y.; Verma, V.; Vaid, R.; Chauhan, R. Bacteriophage therapy: A novel tool for combating bacterial diseases of poultry-A review. J. Immunol. Immunopathol. 2011, 13, 55-66.

145. Mattey, M.; Spencer, J. Bacteriophage therapy—cooked goose or Phoenix rising? Curr. Opin. Biotechnol. 2008, 19, 608-612. [CrossRef] [PubMed]

146. Sulakvelidze, A.; Alavidze, Z.; Morris, J.G. Bacteriophage therapy. Antimicrob. Agents Chemother. 2001, 45, 649-659. [CrossRef] [PubMed]

147. Salvatore, P.P.; Becerra, M.C.; Abel zur Wiesch, P.; Hinkley, T.; Kaur, D.; Sloutsky, A.; Cohen, T. Fitness costs of drug resistance mutations in multidrug-resistant Mycobacterium tuberculosis: A household-based case-control study. J. Infect. Dis. 2016, 213, 149-155. [CrossRef]

148. Ramesh, V.; Fralick, J.A.; Rolfe, R.D. Prevention of Clostridium difficile-induced ileocecitis with bacteriophage. Anaerobe 1999, 5, 69-78. [CrossRef]

149. Nale, J.Y.; Spencer, J.; Hargreaves, K.R.; Buckley, A.M.; Trzepiński, P.; Douce, G.R.; Clokie, M.R. Bacteriophage combinations significantly reduce Clostridium difficile growth in vitro and proliferation in vivo. Antimicrob. Agents Chemother. 2016, 60, 968-981. [CrossRef]

150. Biswas, B.; Adhya, S.; Washart, P.; Paul, B.; Trostel, A.N.; Powell, B.; Carlton, R.; Merril, C.R. Bacteriophage therapy rescues mice bacteremic from a clinical isolate of vancomycin-resistant Enterococcus faecium. Infect. Immun. 2002, 70, 204-210. [CrossRef]

151. Wang, J.; Hu, B.; Xu, M.; Yan, Q.; Liu, S.; Zhu, X.; Sun, Z.; Tao, D.; Ding, L.; Reed, E. Therapeutic effectiveness of bacteriophages in the rescue of mice with extended spectrum $\beta$-lactamase-producing Escherichia coli bacteremia. Int. J. Mol. Med. 2006, 17, 347-355. [CrossRef]

152. Wang, J.; Hu, B.; Xu, M.; Yan, Q.; Liu, S.; Zhu, X.; Sun, Z.; Reed, E.; Ding, L.; Gong, J. Use of bacteriophage in the treatment of experimental animal bacteremia from imipenem-resistant Pseudomonas aeruginosa. Int. J. Mol. Med. 2006, 17, 309-317. [CrossRef] 
153. Watanabe, R.; Matsumoto, T.; Sano, G.; Ishii, Y.; Tateda, K.; Sumiyama, Y.; Uchiyama, J.; Sakurai, S.; Matsuzaki, S.; Imai, S. Efficacy of bacteriophage therapy against gut-derived sepsis caused by Pseudomonas aeruginosa in mice. Antimicrob. Agents Chemother. 2007, 51, 446-452. [CrossRef]

154. Chan, B.K.; Sistrom, M.; Wertz, J.E.; Kortright, K.E.; Narayan, D.; Turner, P.E. Phage selection restores antibiotic sensitivity in MDR Pseudomonas aeruginosa. Sci. Rep. 2016, 6, 26717. [CrossRef]

155. McCormick, A.W.; Whitney, C.G.; Farley, M.M.; Lynfield, R.; Harrison, L.H.; Bennett, N.M.; Schaffner, W.; Reingold, A.; Hadler, J.; Cieslak, P. Geographic diversity and temporal trends of antimicrobial resistance in Streptococcus pneumoniae in the United States. Nat. Med. 2003, 9, 424-430. [CrossRef] [PubMed]

156. Control, C.F.D. Prevention, Emergence of Mycobacterium tuberculosis with extensive resistance to second-line drugs-Worldwide, 2000-2004. MMWR Morb. Mortal. Wkly. Rep. 2006, 55, 301.

157. Alisky, J.; Iczkowski, K.; Rapoport, A.; Troitsky, N. Bacteriophages show promise as antimicrobial agents. J. Infect. 1998, 36, 5-15. [CrossRef]

158. Thiel, K. Old dogma, new tricks-21st century phage therapy. Nat. Biotechnol. 2004, 22, 31-36. [CrossRef]

159. Pirnay, J.-P.; De Vos, D.; Verbeken, G.; Merabishvili, M.; Chanishvili, N.; Vaneechoutte, M.; Zizi, M.; Laire, G.; Lavigne, R.; Huys, I. The phage therapy paradigm: Pret-a-porter or sur-mesure? Pharm. Res. 2011, 28, 934-937. [CrossRef]

160. Brockhurst, M.A.; Morgan, A.D.; Fenton, A.; Buckling, A. Experimental coevolution with bacteria and phage: The Pseudomonas fluorescens- $\Phi 2$ model system. Infect. Genet. Evol. 2007, 7, 547-552. [CrossRef]

161. Cha, K.; Oh, H.K.; Jang, J.Y.; Jo, Y.; Kim, W.K.; Ha, G.U.; Ko, K.S.; Myung, H. Characterization of two novel bacteriophages infecting multidrug-resistant (MDR) Acinetobacter baumannii and evaluation of their therapeutic efficacy in vivo. Front. Microbiol. 2018, 9, 696. [CrossRef]

162. LaVergne, S.; Hamilton, T.; Biswas, B.; Kumaraswamy, M.; Schooley, R.; Wooten, D. Phage therapy for a multidrug-resistant Acinetobacter baumannii craniectomy site infection. In Open Forum Infectious Diseases; Oxford University Press US: New York, NY, USA, 2018; p. ofy064.

163. Lood, R.; Winer, B.Y.; Pelzek, A.J.; Diez-Martinez, R.; Thandar, M.; Euler, C.W.; Schuch, R.; Fischetti, V.A. Novel phage lysin capable of killing the multidrug-resistant gram-negative bacterium Acinetobacter baumannii in a mouse bacteremia model. Antimicrob. Agents Chemother. 2015, 59, 1983-1991. [CrossRef]

164. Witzenrath, M.; Schmeck, B.; Doehn, J.M.; Tschernig, T.; Zahlten, J.; Loeffler, J.M.; Zemlin, M.; Müller, H.; Gutbier, B.; Schütte, H. Systemic use of the endolysin Cpl-1 rescues mice with fatal pneumococcal pneumonia. Crit. Care Med. 2009, 37, 642-649. [CrossRef]

165. Schmelcher, M.; Shen, Y.; Nelson, D.C.; Eugster, M.R.; Eichenseher, F.; Hanke, D.C.; Loessner, M.J.; Dong, S.; Pritchard, D.G.; Lee, J.C. Evolutionarily distinct bacteriophage endolysins featuring conserved peptidoglycan cleavage sites protect mice from MRSA infection. J. Antimicrob. Chemother. 2015, 70, 1453-1465. [CrossRef] [PubMed]

166. Wang, Q.; Euler, C.W.; Delaune, A.; Fischetti, V.A. Using a novel lysin to help control Clostridium difficile infections. Antimicrob. Agents Chemother. 2015, 59, 7447-7457. [CrossRef] [PubMed]

167. Gilmer, D.B.; Schmitz, J.E.; Euler, C.W.; Fischetti, V.A. Novel bacteriophage lysin with broad lytic activity protects against mixed infection by Streptococcus pyogenes and methicillin-resistant Staphylococcus aureus. Antimicrob. Agents Chemother. 2013, 57, 2743-2750. [CrossRef] [PubMed]

168. Shen, Y.; Barros, M.; Vennemann, T.; Gallagher, D.T.; Yin, Y.; Linden, S.B.; Heselpoth, R.D.; Spencer, D.J.; Donovan, D.M.; Moult, J. A bacteriophage endolysin that eliminates intracellular streptococci. eLife 2016, 5, e13152. [CrossRef] [PubMed]

169. Moghadam, M.T.; Khoshbayan, A.; Chegini, Z.; Farahani, I.; Shariati, A. Bacteriophages, a New Therapeutic Solution for Inhibiting Multidrug-Resistant Bacteria Causing Wound Infection: Lesson from Animal Models and Clinical Trials. Drug Des. Dev. Ther. 2020, 14, 1867. [CrossRef] [PubMed]

170. Yang, H.; Wang, D.-B.; Dong, Q.; Zhang, Z.; Cui, Z.; Deng, J.; Yu, J.; Zhang, X.-E.; Wei, H. Existence of separate domains in lysin PlyG for recognizing Bacillus anthracis spores and vegetative cells. Antimicrob. Agents Chemother. 2012, 56, 5031-5039. [CrossRef] [PubMed]

171. Krieg, A.M. CpG motifs: The active ingredient in bacterial extracts? Nat. Med. 2003, 9, 831-835. [CrossRef]

172. Braido, F.; Tarantini, F.; Ghiglione, V.; Melioli, G.; Canonica, G. Bacterial lysate in the prevention of acute exacerbation of COPD and in respiratory recurrent infections. Int. J. Chronic Obstr. Pulm. Dis. 2007, 2, 335.

173. Giovannini, M.; Salvini, F.; Riva, E. Bacterial extracts as immunomodulators for the prevention of recurrent respiratory infections in children. J. Med. Microb. Diagn 2014, 3, 136.

174. Nile, R.S.; Darweesh, M.F.; Al-Rufaie, M.M. Liposomal-lipopolysaccharide vaccine extracted from Proteus mirabilis induces moderate TLR4 and CD14 production. Curr. Issues Pharm. Med. Sci. 2019, 32, 81-86. [CrossRef]

175. Lipsitch, M.; Siber, G.R. How can vaccines contribute to solving the antimicrobial resistance problem? MBio 2016, 7. [CrossRef] [PubMed]

176. Chang, H.-H.; Cohen, T.; Grad, Y.H.; Hanage, W.P.; O’Brien, T.F.; Lipsitch, M. Origin and proliferation of multiple-drug resistance in bacterial pathogens. Microbiol. Mol. Biol. Rev. 2015, 79, 101-116. [CrossRef] [PubMed]

177. Fine, P.E. Herd immunity: History, theory, practice. Epidemiol. Rev. 1993, 15, 265-302. [CrossRef] [PubMed]

178. Levin, B.R.; Cornejo, O.E. The population and evolutionary dynamics of homologous gene recombination in bacteria. PLoS Genet. 2009, 5, e1000601. [CrossRef] [PubMed] 
179. Levin, B.R.; Stewart, F.M.; Rice, V.A. The kinetics of conjugative plasmid transmission: Fit of a simple mass action model. Plasmid 1979, 2, 247-260. [CrossRef]

180. Chevereau, G.; Bollenbach, T. Systematic discovery of drug interaction mechanisms. Mol. Syst. Biol. 2015, 11, 807. [CrossRef] [PubMed]

181. Chait, R.; Craney, A.; Kishony, R. Antibiotic interactions that select against resistance. Nature 2007, 446, 668-671. [CrossRef] [PubMed]

182. Wood, K.B.; Wood, K.C.; Nishida, S.; Cluzel, P. Uncovering scaling laws to infer multidrug response of resistant microbes and cancer cells. Cell Rep. 2014, 6, 1073-1084. [CrossRef]

183. Liu, Y.; Filler, S.G. Candida albicans Als3, a multifunctional adhesin and invasin. Eukaryot. Cell 2011, 10, 168-173. [CrossRef]

184. Schmidt, C.S.; White, C.J.; Ibrahim, A.S.; Filler, S.G.; Fu, Y.; Yeaman, M.R.; Edwards, J.E., Jr.; Hennessey, J.P., Jr. NDV-3, a recombinant alum-adjuvanted vaccine for Candida and Staphylococcus aureus, is safe and immunogenic in healthy adults. Vaccine 2012, 30, 7594-7600. [CrossRef]

185. Tekle, Y.I.; Nielsen, K.M.; Liu, J.; Pettigrew, M.M.; Meyers, L.A.; Galvani, A.P.; Townsend, J.P. Controlling antimicrobial resistance through targeted, vaccine-induced replacement of strains. PLoS ONE 2012, 7, e50688. [CrossRef] [PubMed]

186. Senna, J.P.; Roth, D.M.; Oliveira, J.S.; Machado, D.C.; Santos, D.S. Protective immune response against methicillin resistant Staphylococcus aureus in a murine model using a DNA vaccine approach. Vaccine 2003, 21, 2661-2666. [CrossRef]

187. Lee, N.; Yuen, K.-Y.; Kumana, C.R. Clinical role of $\beta$-lactam/ $\beta$-lactamase inhibitor combinations. Drugs 2003, 63, 1511-1524. [CrossRef] [PubMed]

188. Zarantonelli, M.L.; Antignac, A.; Lancellotti, M.; Guiyoule, A.; Alonso, J.-M.; Taha, M.-K. Immunogenicity of meningococcal PBP2 during natural infection and protective activity of anti-PBP2 antibodies against meningococcal bacteraemia in mice. J. Antimicrob. Chemother. 2006, 57, 924-930. [CrossRef]

189. Leuzzi, R.; Adamo, R.; Scarselli, M. Vaccines against Clostridium difficile. Hum. Vaccines Immunother. 2014, 10, 1466-1477. [CrossRef]

190. Priebe, G.P.; Goldberg, J.B. Vaccines for Pseudomonas aeruginosa: A long and winding road. Expert Rev. Vaccines 2014, 13, 507-519. [CrossRef]

191. Singh, V.; Bala, M.; Bhargava, A.; Kakran, M.; Bhatnagar, R. In vitro efficacy of 21 dual antimicrobial combinations comprising novel and currently recommended combinations for treatment of drug resistant gonorrhoea in future era. PLoS ONE 2018, 13, e0193678. [CrossRef]

192. Ginsberg, A.M.; Spigelman, M. Challenges in tuberculosis drug research and development. Nat. Med. 2007, 13, 290-294. [CrossRef]

193. Young, D.B.; Perkins, M.D.; Duncan, K.; Barry, C.E. Confronting the scientific obstacles to global control of tuberculosis. J. Clin. Investig. 2008, 118, 1255-1265. [CrossRef]

194. Hansen, J.L.; Moore, P.B.; Steitz, T.A. Structures of five antibiotics bound at the peptidyl transferase center of the large ribosomal subunit. J. Mol. Biol. 2003, 330, 1061-1075. [CrossRef]

195. Tu, D.; Blaha, G.; Moore, P.B.; Steitz, T.A. Structures of MLSBK antibiotics bound to mutated large ribosomal subunits provide a structural explanation for resistance. Cell 2005, 121, 257-270. [CrossRef] [PubMed]

196. Cocito, C. Antibiotics of the virginiamycin family, inhibitors which contain synergistic components. Microbiol. Rev. 1979, $43,145$. [CrossRef] [PubMed]

197. Babb, R.; Pirofski, L.-A. Help is on the way: Monoclonal antibody therapy for multi-drug resistant bacteria. Virulence 2017, 8 , 1055-1058. [CrossRef] [PubMed]

198. Guachalla, L.M.; Ramoni, K.; Varga, C.; Mutti, M.; Ghazawi, A.; Pál, T.; Nagy, E.; Sonnevend, Á.; Nagy, G.; Szijártó, V. Retained activity of an $\mathrm{O} 25 \mathrm{~b}$-specific monoclonal antibody against an Mcr-1-producing Escherichia coli sequence type 131 strain. Antimicrob. Agents Chemother. 2018, 62. [CrossRef]

199. Thanabalasuriar, A.; Surewaard, B.G.; Willson, M.E.; Neupane, A.S.; Stover, C.K.; Warrener, P.; Wilson, G.; Keller, A.E.; Sellman, B.R.; DiGiandomenico, A. Bispecific antibody targets multiple Pseudomonas aeruginosa evasion mechanisms in the lung vasculature. J. Clin. Investig. 2017, 127, 2249-2261. [CrossRef]

200. Motterlini, R.; Otterbein, L.E. The therapeutic potential of carbon monoxide. Nat. Rev. Drug Discov. 2010, 9, 728-743. [CrossRef]

201. Romão, C.C.; Blättler, W.A.; Seixas, J.D.; Bernardes, G.J. Developing drug molecules for therapy with carbon monoxide. Chem. Soc. Rev. 2012, 41, 3571-3583. [CrossRef]

202. García-Gallego, S.; Bernardes, G.J. Carbon-monoxide-releasing molecules for the delivery of therapeutic CO in vivo. Angezw. Chem. Int. Ed. 2014, 53, 9712-9721. [CrossRef]

203. Nobre, L.S.; Jeremias, H.; Romão, C.C.; Saraiva, L.M. Examining the antimicrobial activity and toxicity to animal cells of different types of CO-releasing molecules. Dalton Trans. 2016, 45, 1455-1466. [CrossRef]

204. Ouwehand, A.C.; Forssten, S.; Hibberd, A.A.; Lyra, A.; Stahl, B. Probiotic approach to prevent antibiotic resistance. Ann. Med. 2016, 48, 246-255. [CrossRef]

205. Halder, D.; Mandal, S. Insights into the antagonism of Lactobacillus fermentum curd isolate against Gram-positive and Gramnegative pathogenic bacteria. Biosci. Biotechnol. Res. Commun. 2018, 11, 461-468. [CrossRef] 
206. Nair, D.V.; Kollanoor Johny, A. Characterizing the antimicrobial function of a dairy-originated probiotic, Propionibacterium freudenreichii, against multidrug-resistant Salmonella enterica serovar Heidelberg in turkey poults. Front. Microbiol. 2018, 9, 1475. [CrossRef] [PubMed]

207. Kiran, M.D.; Adikesavan, N.V.; Cirioni, O.; Giacometti, A.; Silvestri, C.; Scalise, G.; Ghiselli, R.; Saba, V.; Orlando, F.; Shoham, M. Discovery of a quorum-sensing inhibitor of drug-resistant staphylococcal infections by structure-based virtual screening. Mol. Pharmacol. 2008, 73, 1578-1586. [CrossRef] [PubMed]

208. Smith, D.; Wiegeshaus, E.; Navalkar, R.; Grover, A. Host-parasite relationships in experimental airborne tuberculosis I. Preliminary studies in BCG-vaccinated and nonvaccinated animals. J. Bacteriol. 1966, 91, 718-724. [CrossRef]

209. Janeway, C.A.; Travers, P.; Walport, M.; Shlomchik, M. Immunobiology: The Immune System in Health and Disease. 2005; Garland Science: New York, NY, USA, 2017; Volume 6.

210. Davis, M.M.; Bjorkman, P.J. T-cell antigen receptor genes and T-cell recognition. Nature 1988, 334, 395-402. [CrossRef]

211. Alberts, B.; Johnson, A.; Lewis, J.; Raff, M.; Roberts, K.; Walter, P. B Cells Antibodies. In Molecular Biology of the Cell, 4th ed.; Garland Science: New York, NY, USA, 2002.

212. Dhesi, Z.; Enne, V.I.; Justin, O.G.; Gant, V.; Livermore, D.M. Rapid and Point-of-Care Testing in Respiratory Tract Infections: An Antibiotic Guardian? ACS Pharmacol. Transl. Sci. 2020, 3, 401-417. [CrossRef]

213. Mitsakakis, K.; Kaman, W.E.; Elshout, G.; Specht, M.; Hays, J.P. Challenges in identifying antibiotic resistance targets for point-of-care diagnostics in general practice. Future Microbiol. 2018, 13, 1157-1164. [CrossRef]

214. Anderson, M.E.; O’Brien, E.C.; Grayek, E.N.; Hermansen, J.K.; Hunt, H.K. The detection of Helicobacter hepaticus using whispering-gallery mode microcavity optical sensors. Biosensors 2015, 5, 562-576. [CrossRef]

215. Jiang, X.; Qavi, A.J.; Huang, S.H.; Yang, L. Whispering-Gallery Sensors. Matter 2020, 3, 371-392. [CrossRef]

216. Jiang, X.; Qavi, A.J.; Huang, S.H.; Yang, L. Whispering gallery microsensors: A review. arXiv 2018, arXiv:1805.00062.

217. Vahala, K.J. Optical microcavities. Nature 2003, 424, 839-846. [CrossRef] [PubMed]

218. Foreman, M.R.; Swaim, J.D.; Vollmer, F. Whispering gallery mode sensors. Adv. Opt. Photonics 2015, 7, 168-240. [CrossRef] [PubMed]

219. Cai, L.; Pan, J.; Zhao, Y.; Wang, J.; Xiao, S. Whispering Gallery Mode Optical Microresonators: Structures and Sensing Applications. Phys. Status Solidi (A) 2020, 217, 1900825. [CrossRef] 